This article was published as: Ali Fadel, Bruno Lemaire, Brigitte Vinçon-Leite, Ali Atoui, Kamal Slim, et al. (2017). On the successful use of a simplified model to simulate the succession of toxic cyanobacteria in a hypereutrophic reservoir with a highly fluctuating water level. Environmental Science and Pollution Research, 24 (26), pp.20934 - 20948. DOI : 10.1007/s11356-017-9723-9

\title{
On the successful use of a simplified model to simulate the succession of toxic cyanobacteria in a hypereutrophic reservoir with a highly fluctuating water level
}

\author{
Ali FADEL ${ }^{*}$, Bruno J. LEMAIRE ${ }^{2}$, Brigitte Vinçon-Leite ${ }^{2}$, Ali ATOUI ${ }^{3}$, Kamal SLIM ${ }^{3}$, \\ Bruno TASSIN ${ }^{2}$ \\ ${ }^{1}$ National Center for Remote Sensing, National Council for Scientific Research, P.O. Box 11-8281, Riad El \\ Solh, 11072260 Beirut, Lebanon \\ ${ }^{2}$ Université Paris-Est, LEESU, UPEC, Ecole des Ponts ParisTech, AgroParisTech, F-77455 Marne-la-Vallée, \\ France \\ ${ }^{3}$ Laboratory of Microorganisms and Food Irradiation, Lebanese Atomic Energy Commission- CNRS, P.O. Box \\ 11-8281, Riad El Solh, 11072260 Beirut, Lebanon
}

*Author to whom correspondence should be addressed; E-Mail: afadel@cnrs.edu.lb; Tel.: + 961 (0)4 409 845; Fax: + 961 (0)4 409847

\begin{abstract}
Many freshwater bodies worldwide that suffer from harmful algal blooms would benefit for their management from a simple ecological model that requires few field data, e.g., for early warning systems. Beyond a certain degree, adding processes to ecological models can reduce model predictive capabilities. In this work, we assess whether a simple ecological model without nutrients is able to describe the succession of cyanobacterial blooms of different species in a hypereutrophic reservoir and help understand the factors that determine these blooms. In our study site, Karaoun Reservoir, Lebanon, cyanobacteria Aphanizomenon ovalisporum and Microcystis aeruginosa alternatively bloom. A simple configuration of the model Dyresm-Caedym was used: both cyanobacteria were simulated, with constant vertical migration velocity for Aphanizomenon ovalisporum, with vertical migration velocity dependent on light for Microcystis aeruginosa and with growth limited by light and temperature and not by nutrients for both species. The model was calibrated on two successive years with contrasted bloom patterns and high variations in water level. It was able to reproduce the measurements: it showed a good performance for the water level (root mean square error (RMSE) lower than $1 \mathrm{~m}$, annual variation of $25 \mathrm{~m}$ ), water temperature profiles (RMSE of $0.22-1.41{ }^{\circ} \mathrm{C}$, range $13-28{ }^{\circ} \mathrm{C}$ ) and cyanobacteria biomass (RMSE of $1-57 \mu \mathrm{g}$ Chl $a \mathrm{~L}^{-1}$, range 0-206 $\mu \mathrm{g} \mathrm{Chl} a \mathrm{~L}^{-1}$ ). The model also helped understand the succession of blooms in both years. The model results suggest that the higher growth rate of Microcystis aeruginosa during favourable temperature and light conditions allowed it to outgrow Aphanizomenon ovalisporum. Our results show that simple model configurations not only can be sufficient for theoretical works when few major processes can be identified, but also for operational applications. This approach could be transposed on other hypereutrophic lakes and reservoirs to describe the competition between dominant phytoplankton species, contribute to early warning systems or be used for management scenarios.
\end{abstract}

Keywords: Dyresm-Caedym; Model simplicity; Cyanobacteria succession, water level variation 


\section{Introduction}

Since eutrophication is still a problem in many lakes and reservoirs worldwide (Istvanovics 2010; Smith 2003), ecosystem models remain beneficial and essentially needed to increase the understanding of the fundamental processes in lake ecosystems (Jørgensen, 2010; Mooij et al., 2010; Trolle et al., 2012). Many lake ecosystem models have been developed and published during the past decades, and a wide diversity of approaches has been used to model phytoplankton biomass at the ecosystem scale (Janssen et al., 2015; Mooij et al., 2010). These models include Delft3D-ECOLOGY, PROTECH, PCLAKE, IPH-TRIM3D-PCLAKE, MyLake, ALMO, GLM-AED, MELODIA. They are used to test management scenarios and simulate consecutive changes in water temperature, phytoplankton groups, zooplankton and nutrients (Akomeah et al. 2015; Vieira et al. 2013; Khemakhem et al. 2013). Up-to-date ecosystem models often require large input data due to their complexity (Bruce et al., 2006; Gal et al., 2009). However, many freshwater bodies throughout the world that suffer harmful algal blooms do not possess large data sets of several environmental variables. Beyond a certain degree, adding processes was shown to reduce model predictive capabilities so that simple models that use few field data are more adapted to meet operational applications (McDonald and Urban, 2010; Mieleitner and Reichert, 2008). Many reservoirs are characterized by frequent fluctuations in their water level (Wantzen et al., 2008). These fluctuations affect phytoplankton biomass and species composition through their effect on mixing processes, biogeochemical processes, oxygen dynamics, and underwater light climate (Naselli-Flores and Barone, 1997; Valdespino-Castillo et al., 2014). Their amplitude and frequency are modified by climate change because of changes in the occurrence of drought and heavy rainfall episodes (Callieri et al., 2014). To our best knowledge, few studies applied a model to reservoirs with high fluctuating water levels: the highest annual variation, $10 \mathrm{~m}$ out of $38 \mathrm{~m}$, is in El Gergal Reservoir in Spain, modelled with Dyresm-Caedym (Rigosi et al. 2011).

Few numerical studies with a coupled hydrodynamical-ecological model focused on the succession between phytoplankton groups and species. Dyresm-Caedym was applied to simulate phytoplankton succession, in Lake Kinneret (Gal et al., 2009) and in El Gergal Reservoir (Rigosi et al. 2011). However, the biological model was highly complex and contained many parameters to simulate not only phytoplankton but also nutrients, dissolved oxygen, $\mathrm{pH}$, zooplankton and bacteria. Rigosi et al. (2011) proposed a calibration strategy for Dyresm-Caedym to reproduce the seasonal succession of the phytoplankton groups of El Gergal Reservoir using large data set and not at the species level. All the previously quoted studies that applied Dyresm-Caedym either simulated phytoplankton groups rather than species or used a complex model configuration and an outstanding data set unreachable to most lake managers. Neither are there any applications of hydrodynamic-ecological models on lakes and reservoirs in the Middle East except for Lake Kinneret (Gal et al., 2009; Fadel 2014).

In this paper we use a comparatively simple one-dimensional ecosystem model, coupled to a hydrodynamic model, to investigate the factors that determine the succession of two bloomforming cyanobacteria species in an artificial reservoir in Lebanon with high water level variations. We start by presenting the study site, the data set including our field measurements, and the model configuration. In the results section, we present the thermal and biological simulations and the controlling factors of the succession between Aphanizomenon ovalisporum and Microcystis aeruginosa according to the model. We then discuss the model 
performance, the influence of the water level variation and the implications of our results for hypereutrophic reservoir management.

\section{Materials and Methods \\ 2.1 Study site}

Karaoun Reservoir, located in the Southern Bekaa valley, between the two Lebanese mountain chains, is the largest freshwater body in Lebanon (Figure 1). The reservoir, used for hydropower and irrigation, was constructed between 1958 and 1965 on the Litani River (170 $\mathrm{km}$ length). Table 1 presents its morphometric and hydrologic characteristics. The $25 \mathrm{~m}$ average annual water level variation makes the reservoir an interesting study case in a poorly studied region (Fadel et al., 2015).

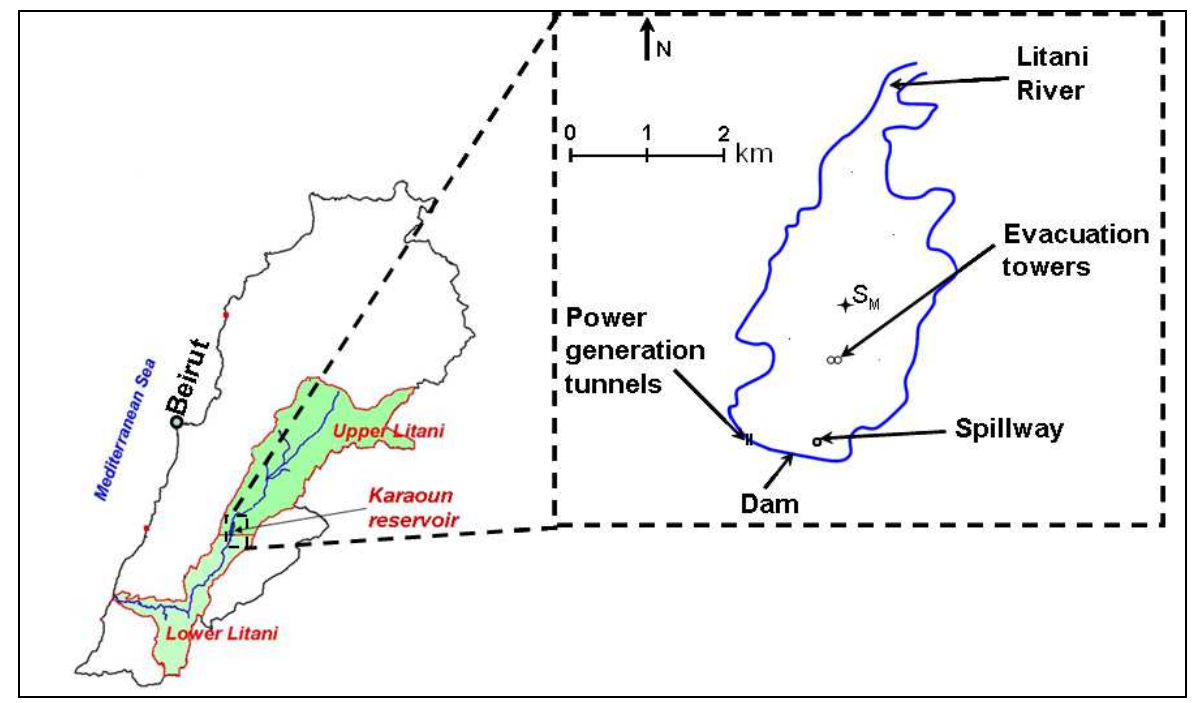

Figure 1 Karaoun Reservoir and sampling site $\mathbf{S}_{M}$.

Table 1 Karaoun reservoir morphometric and hydrologic characteristics.

\begin{tabular}{|c|c|}
\hline Surface area at full capacity & $12 \mathrm{~km}^{2}$ \\
\hline Maximum storage capacity & $224 \times 10^{6} \mathrm{~m}^{3}$ \\
\hline Maximum depth & $60 \mathrm{~m}$ \\
\hline Mean depth at full capacity & $19 \mathrm{~m}$ \\
\hline Altitude of maximum water level (spillway) & $860 \mathrm{~m}$ \\
\hline Altitude of water withdrawal & $810 \mathrm{~m}$ \\
\hline Catchment area & $1600 \mathrm{~km}^{2}$ \\
\hline
\end{tabular}

There are about one million inhabitants as well as $570 \mathrm{~km}^{2}$ of cultivated farmland and several industries in the catchment of Karaoun Reservoir. The Litani River receives domestic sewage and agricultural drainage containing nutrients all year long. As a result, the reservoir is hypereutrophic. Toxic cyanobacteria Microcystis aeruginosa and the nitrogen fixing cyanobacterium Aphanizomenon ovalisporum alternatively bloom in the reservoir and trouble irrigation and hydropower production by clogging pumps and turbines (Fadel et al., 2014a; Slim et al., 2014; Temsah et al., 2016). Karaoun Reservoir represents an interesting study case to assess the performance of a simplified model to describe the seasonal succession of cyanobacterial blooms, with a limited database and a highly varying water level. 


\subsection{Site data}

\subsubsection{Hydrological data}

The bathymetry of Karaoun Reservoir was determined with sonar in Spring 2012 by the Litani River Authority.

The Litani River Authority weekly monitors the water level. The main reservoir input is the inflow from the Litani River (Figure 2). The inflow file of Dyresm-Caedym includes daily temperature, salinity and nutrient concentrations entering the reservoir through the river inflow. However, since such daily river water quality data is not always available, daily values were linearly interpolated between weekly and bimonthly samplings.

The reservoir withdrawals are used for hydropower generation and for irrigation. The reservoir hydrologic balance also includes inflow from underwater springs, evaporation, precipitation and infiltration due to the karstic geological environment. More details about the reservoir functioning and hydrology are presented in (Fadel et al., 2014b).

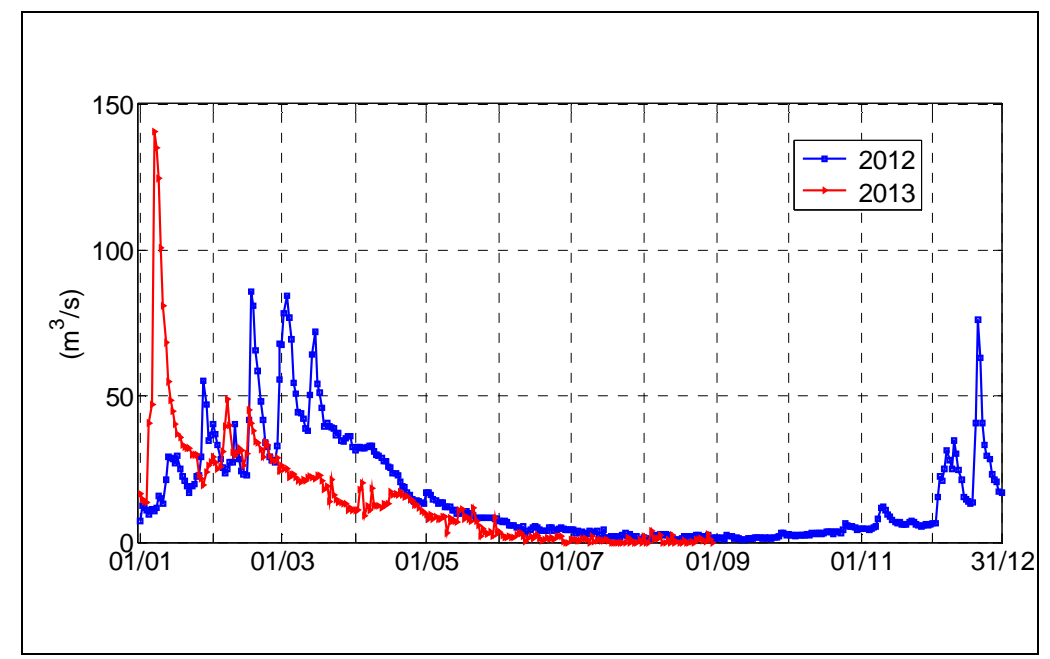

Figure 2 Litani River inflow rate into Karaoun Reservoir during 2012 and 2013

\subsubsection{Meteorological data}

Meteorological data, required as input to the model, were taken from the closest functioning meteorological station in Tal-Amara. The station is located in the Bekaa valley ( $33^{\circ}$ '51' $50^{\prime}$ " N, 35 59' 06” E), at an altitude of 905 m, 40 km North of Karaoun Reservoir. Daily averages were used for solar radiation, air temperature, relative humidity and wind speed as well as daily rainfall (Figure 3). Due to the absence of cloud cover measurements, daily values were considered as 1 when it rained during the day, 0 else. Vapour pressure was calculated from relative humidity and air temperature using the Magnus-Tetens formula (Tennessee Valley Authority, 1972). 


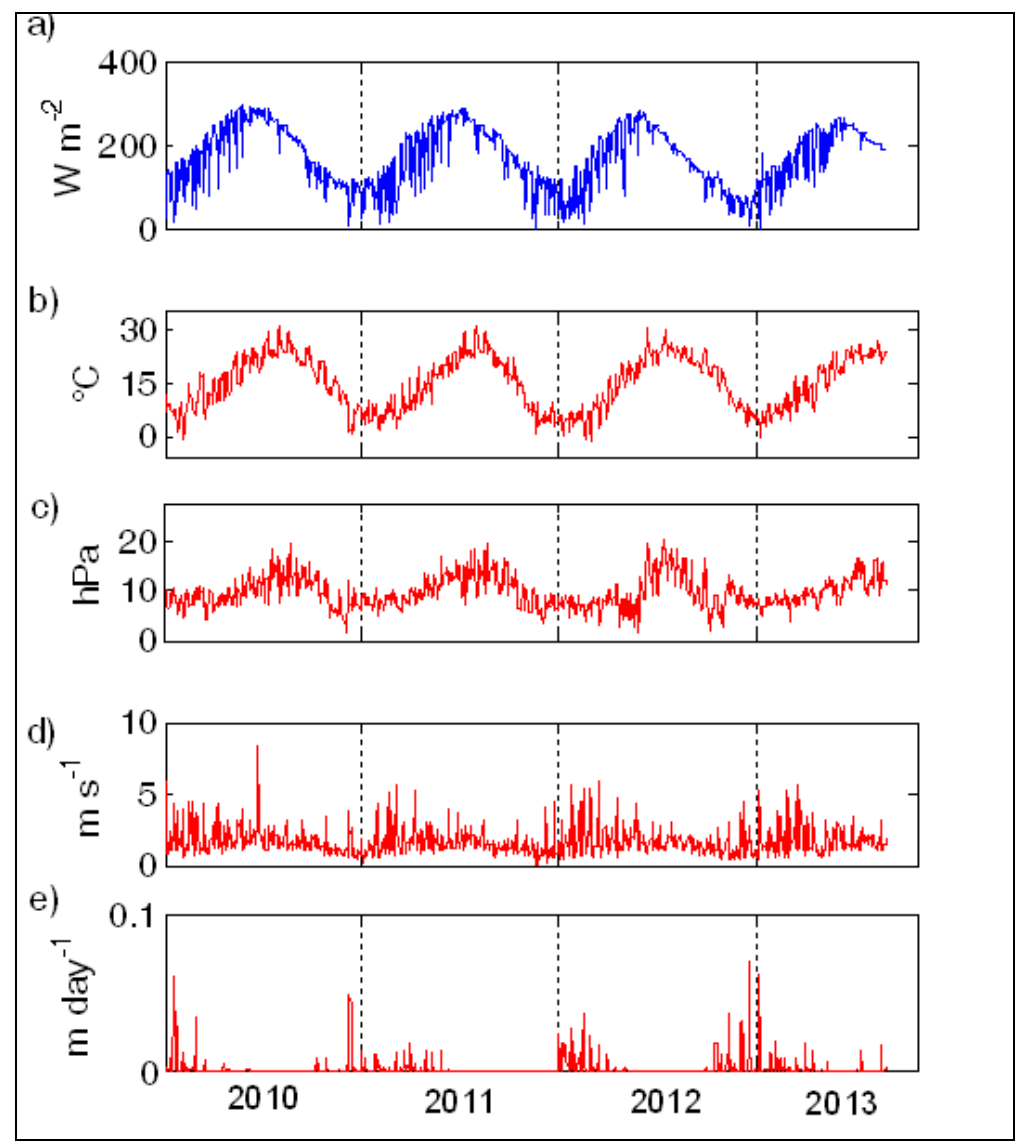

Figure 3 Daily average meteorological data used as input to the model (January 2010-August 2013). Data were obtained from Tal-Amara climate station. a) solar radiation, b) air temperature, c) vapour pressure calculated from the measured relative humidity and air temperature, d) wind speed and e) rainfall

\subsubsection{Field measurements}

Water temperature was continuously measured, each 15 min with temperature sensors (Starmon mini, Star-Oddi) at the spillway location to limit the vandalism risk. Sensors, attached to a buoy, were located at 1, 4, 7, 10,13,16 and $19 \mathrm{~m}$ depths. The sensor measuring range is -2 to $40{ }^{\circ} \mathrm{C}$ with an accuracy of $0.05{ }^{\circ} \mathrm{C}$. The lower temperature sensors were progressively removed when the water level decreased.

All other measurements and samples were taken from the middle of the lake $\left(33^{\circ} 34^{\prime} 05^{\prime \prime} \mathrm{N}\right.$, $35^{\circ} 41^{\prime}$ 44'E). Campaigns were performed bi-weekly between 11:00 and 13:00. Water transparency was measured with Secchi disk. A submersible fluorometer (TriOS microFlublue) was used to measure fluorescence profiles of phycocyanin, a pigment specific to cyanobacteria. It is equipped with ultra-bright red LEDs, of excitation wavelength $620 \mathrm{~nm}$, detection wavelength $655 \mathrm{~nm}$ and band-width $10 \mathrm{~nm}$. It gives a linear response to phycocyanin concentration up to $200 \mu \mathrm{g}$ Chl $a \mathrm{~L}^{-1}$ with an accuracy of $0.02 \mu \mathrm{g} \mathrm{Chl} a \mathrm{~L}^{-1}$. Measurements were performed every half meter between the surface and the bottom of the reservoir by descending the cable manually.

Water samples were collected using borosilicate glass bottles at $0.5 \mathrm{~m}$ depth from May to November 2012 and at 0.5, 5 and $10 \mathrm{~m}$ depths from March to August 2013 with a vertical Niskin bottle of $2.2 \mathrm{~L}$ capacity (Wildco $1120-\mathrm{D} 42$ ). Samples were stored at $4^{\circ} \mathrm{C}$ until further 
processing in the laboratory. Different volumes and bottles were used for phytoplankton identification and counting.

The subsamples used for phytoplankton counting were fixed by formaldehyde ( $4 \%$ of sample volume) and preserved at $4{ }^{\circ} \mathrm{C}$. The phytoplankton species were determined on the sampling day according to taxonomic keys based on cell structure and dimensions, colony morphology, and mucilage characteristics (Komárek and Anagnostidis, 1999, 2005). Microscopic identification and enumeration were carried out under a phase contrast microscope (Nikon TE200, Nikon, Melville, NY, USA), under a $\times 40$ objective and using a Nageotte chamber that accepts $100 \mu \mathrm{L}$ on 40 bands. The number of counted bands depended on sample concentration. Each subsample was counted in triplicate.

\subsection{Model}

We used in this study a one-dimensional vertical hydrodynamic and ecological model, Dyresm-Caedym, designed by the Centre for Water Research (CWR, Australia) (Imberger and Patterson, 1981; Hamilton and Schladow, 1997). It is the most used ecological model for lake ecosystems (Trolle et al., 2012). The model was mostly applied on lakes with stable water level like Lake Ammersee in Germany (Weinberger and Vetter, 2012), Lake Constance (Rinke et al., 2010), but also on many freshwater bodies throughout the world that share comparable physical characteristics or phytoplankton community with Karaoun Reservoir, e.g., Lake Pusiano in Italy (Copetti et al., 2006), Sau Reservoir in Spain (Takkouk and Casamitjana, 2015), Terauchi Dam in Japan (Asaeda et al., 2001), El Gergal Reservoir in Spain (Rigosi et al., 2011), Lake Mendota in USA (Kara et al., 2012), Shahe Reservoir in China (Cui et al., 2016), and Lake Kinneret (Gal et al., 2009; Rinke et al., 2010; Yeates and Imberger, 2003).

Dyresm simulates the vertical distribution of temperature, salinity and density in the water column (Imberger, 1978; Imberger, 1981; Yeates and Imberger, 2003). Caedym can simulate $\mathrm{C}, \mathrm{N}, \mathrm{P}, \mathrm{Si}$ and dissolved oxygen cycles, inorganic suspended solids, zooplankton and phytoplankton dynamics (Hipsey, 2007). Robson and Hamilton (2004) and Romero et al. (2004) gave a detailed description of the model equations.

\subsubsection{Simplified model configuration}

We configured Dyresm-Caedym to simulate changes in water level, water temperature and the biomasses of two cyanobacteria species at point $S_{M}$ (Figure 1). Figure 4 presents the conceptual diagram of the simple hydro-dynamic ecological model applied to Karaoun Reservoir based on weather and water flow inputs and initial measured profiles.

The equations of the biological model selected in Caedym are presented in Table 2. The dynamics of two cyanobacteria groups was simulated.

In winter, the average nutrient concentrations in the Litani River inflow into Karaoun Reservoir are $9 \mathrm{mg} \mathrm{L}^{-1}$ for nitrate, $1.9 \mathrm{mg} \mathrm{L}^{-1}$ for ammonium and $1.1 \mathrm{mg} . \mathrm{L}^{-1}$ for orthophosphate. In summer, concentrations are higher with $9.6 \mathrm{mg} \mathrm{L}^{-1}$ for nitrate, $3.7 \mathrm{mg} \mathrm{L}^{-1}$ for ammonium and $2.1 \mathrm{mg} \mathrm{L}^{-1}$ for orthophosphate (USAID 2012). This results in continuous availability of both nitrogen and phosphorus in the reservoir (Fadel et al., 2014b): nutrients can be regarded as non-limiting factors of phytoplankton growth. That is why the phosphorus and nitrogen limitations were deactivated in Caedym by setting the Michaelis-Menten constants for nitrogen and phosphorus to 0 , and by choosing the following values for internal nutrient concentrations: $10^{-5} \mathrm{mg} / \mathrm{mg} \mathrm{Chl} a$ for minimal nitrogen and phosphorus 
concentrations and $9 \mathrm{mg} / \mathrm{mg} \mathrm{Chl} a$ for maximal nitrogen and phosphorus concentrations. With such a configuration, simulations are independent from nutrients.

Both cyanobacteria are subject to photoinhibition.

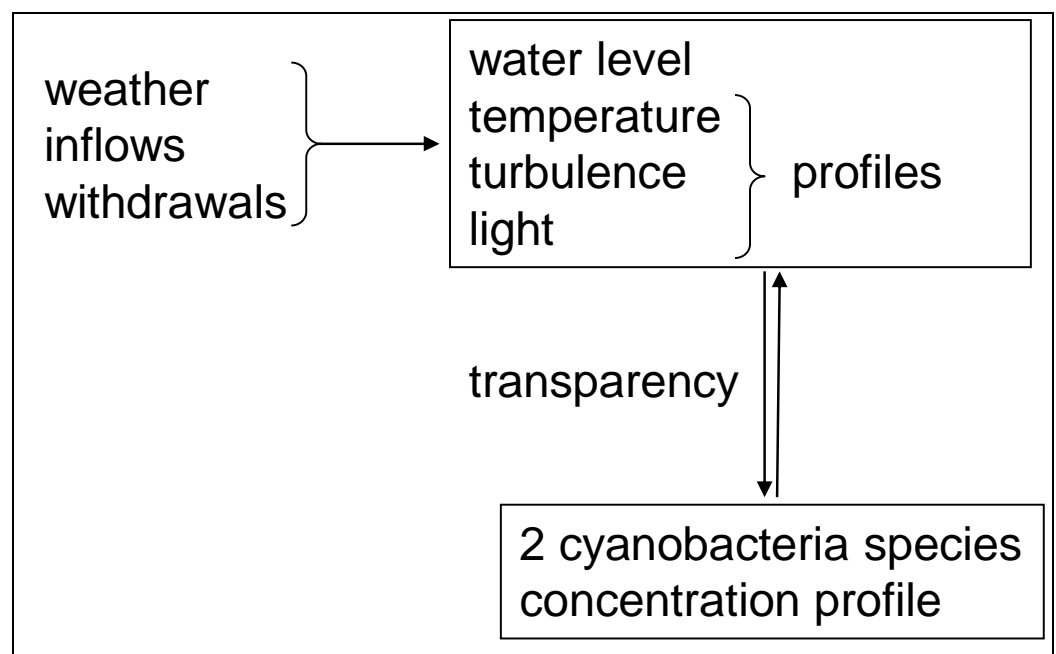

Figure 4 Conceptual diagram of the simple hydro-dynamic ecological model applied to Karaoun Reservoir

A vertical velocity dependent on light was used to present the upward and downward migration of Microcystis aeruginosa. A constant small rising velocity was used for Aphanizomenon ovalisporum.

Due to the absence of precise data about zooplankton biomass in Karaoun Reservoir, the effect of zooplankton grazing on phytoplankton was not simulated explicitly; however, its contribution to phytoplankton mortality was included in the model through a loss term that also included respiration and excretion.

Table 2 Equations selected in CAEDYM after simplification

\begin{tabular}{|l|l|}
\hline $\begin{array}{l}\text { Biomass of cyanobacterium species } i \text { at } \\
\text { depth } z\end{array}$ & $\frac{\partial C_{i}(z, t)}{\partial t}=\left(\mu_{g, i}(I, T)-L_{i}(T)\right) C_{i}(z, t)+v_{i} \frac{\partial C_{i}(z, t)}{\partial z}$ \\
\hline Cyanobacterium $i$ growth rate & $\mu_{g, i}(I, T)=\mu_{\text {max }, i} f_{i}(I) g_{i}(T)$ \\
\hline Light limitation factor & $f_{i}(I)=\frac{I}{I_{s, i}} \exp \left(1-\frac{I}{I_{s, i}}\right)$ \\
\hline Temperature limitation factor & $g_{i}(T)=\theta^{T-T_{s t d}}-\theta^{k_{i}\left(T-a_{i}\right)}+b_{i}$ \\
\hline $\begin{array}{l}\text { Vertical migration velocity of } \\
\text { Microcystis aeruginosa (index 1): }\end{array}$ & $v_{1}=c_{4} f_{1}(I)-c_{5}$ \\
\hline $\begin{array}{l}\text { Vertical migration velocity of } \\
\text { Aphanizomenon ovalisporum (index 2) }\end{array}$ & constant rising speed $v_{2}$ \\
\hline Loss rate & $L_{i}(T)=k_{r a, i} \vartheta_{i}^{T-T_{s t d}}$ \\
\hline Light extinction & $I(z)=0.45 I(0) \exp \left[-\left(K_{0}+\sum_{i} K_{e p, i} C_{i}\right) z\right]$ \\
\hline
\end{tabular}

Where $C_{i}$ is the biomass of cyanobacterium species $i, \mu_{g, i}$ its growth rate, $L_{i}$ its loss rate, $v_{i}$ its vertical migration velocity, $\mu_{\text {max }, \mathrm{i}}$ the maximum growth rate at standard temperature $\mathrm{T}_{\text {std }}\left(20^{\circ} \mathrm{C}\right)$; 
$\mathrm{I}(\mathrm{z})$ is the photosynthetically active radiation reaching depth $\mathrm{z}$ and $\mathrm{I}_{\mathrm{s}, \mathrm{i}}$ the saturation irradiance, at which growth is maximal;

the parameters $\mathrm{k}_{\mathrm{i}}, \mathrm{a}_{\mathrm{i}}$ and $\mathrm{b}_{\mathrm{i}}$ are solved numerically to satisfy the following conditions: $\mathrm{g}_{\mathrm{i}}\left(\mathrm{T}_{\mathrm{std}}\right)=1$ at the reference temperature $\mathrm{T}_{\mathrm{std}} ; \mathrm{dg}_{\mathrm{i}} / \mathrm{dT}\left(\mathrm{T}_{\mathrm{opt}, \mathrm{i}}\right)=0$, at the optimal temperature $\mathrm{T}_{\mathrm{opt}, \mathrm{i}}, \mathrm{g}_{\mathrm{i}}\left(\mathrm{T}_{\mathrm{max}, \mathrm{i}}\right)=0$ at the maximum temperature $\mathrm{T}_{\text {max }, \mathrm{i}} ; \theta$ is the constant for temperature limitation (1.07);

$\mathrm{V}_{\mathrm{i}}$, cyanobacterium migration velocity of species $\mathrm{i}$, is negative for settling and positive for buoyancy; $\mathrm{c}_{5}$ is a constant background settling velocity in this model configuration without nutrients and $\mathrm{c}_{4}$ a calibrated coefficient for light dependence;

$\mathrm{k}_{\mathrm{ra}, \mathrm{i}}$ is the loss rate coefficient of species $\mathrm{i}$ (includes effect of mortality and excretion) and $\vartheta_{\mathrm{i}}$ its temperature constant ;

$\mathrm{K}_{0}$ is the background light extinction coefficient, $\mathrm{K}_{\mathrm{ep}, \mathrm{i}}$ the specific light extinction coefficient due to species $\mathrm{i}$ (for Dyresm simulations alone, there is no shading by cyanobacteria and the extinction coefficient is constant).

\subsubsection{Model calibration and verification}

Simulations were set up with a 1-day time step for input and output variables. Daily mean water temperature profiles measured at the spillway and cyanobacteria concentration profiles measured in the middle of the reservoir were used to provide the initial conditions of the model.

The performance of the hydrodynamic model Dyresm in simulating the reservoir water level was assessed on the years 2010, 2011 and 2012 for which water level measurements were available: the model was calibrated on 2012 and verified on 2010 and 2011 separately. The calibration was based on trial-and-error manual adjustment of model parameter values until the model simulations matched the observed values with lowest root mean square error (RMSE).

The hydrodynamic model Dyresm was first calibrated to obtain a correct water balance and water temperature profiles. Water temperature simulations were compared to measurements at $1,4,7,10,13,16$ and $19 \mathrm{~m}$ depths at the spillway.

The maximum and minimum layer thicknesses were adjusted to reproduce correctly the thermocline. The light extinction coefficient was calibrated to control heat transfer to the deeper layers and the vertical mixing coefficient for mixing the hypolimnion. Default values were used for all other parameters. Wind speed at the weather station, $40 \mathrm{~km}$ to the north of Karaoun Reservoir, close to the mountains, was expected to be lower than on the lake in the middle of the valley. Therefore, it was corrected by an additional calibration factor in order to improve the mixing in the lake epilimnion as in Hornung (2002) on Lake Constance (Table $3)$.

The coupled hydrodynamic and biological model Dyresm-Caedym was calibrated on a 6month period between 24 May and 20 November 2012 and verified on a 3-month period between 15 May and 21 August 2013. Both model runs were initialized with a set of observed temperature and cyanobacteria measurements. These periods in which we performed biological, cover both increases and decreases in water level and biomass of cyanobacterial species. Cyanobacterial simulations were compared to phycocyanin fluorescence measured at 1,5 and $10 \mathrm{~m}$ at point $\mathrm{S}_{\mathrm{M}}$. Modelled biomass values are expressed in $\mu \mathrm{g} \mathrm{Chl} a \mathrm{~L}^{-1}$. The phycocyanin to chlorophyll-a stoechiometric ratio ranges between 1 and 1.66 for Microcystis aeruginosa and other cyanobacterial species (Watras and Baker, 1988). For comparing model results to measurements, we converted phycocyanin concentrations to chlorophyll-a concentrations by multiplying it with a factor of 1.33 with an uncertainty of $30 \%$. The biological parameters were calibrated within ranges given by literature (Table 4). 
Table 3 Parameter values used for DYRESM to simulate Karaoun Reservoir water level and temperature

\begin{tabular}{|lll|}
\hline Parameters (unit) & $\begin{array}{l}\text { Assigned } \\
\text { values }\end{array}$ & References \\
\hline Mean albedo of water (-) & 0.08 & Patten et al., 1975 \\
Bulk aerodynamic transport coefficient (-) & 0.0019 & Stull, 1988 \\
Emissivity of a water surface (-) & 0.96 & Imberger and Patterson, 1981 \\
Effective surface area coefficient & $10^{7}$ & Yeates and Imberger, 2003 \\
Critical wind speed (m s s $\left.^{-1}\right)$ & 3 & Default \\
Wind stirring efficiency (-) & 0.9 & Default \\
Potential energy mixing efficiency (-) & 0.2 & Spigel et al., 1986 \\
Shear production efficiency (-) & 0.08 & Spigel et al., 1986 \\
\hline Vertical mixing coefficient $(-)$ & 2500 & Calibrated \\
Wind multiplication factor $(-)$ & 1.3 & Calibrated \\
Minimum layer thickness (m) & 0.25 & Calibrated \\
Maximum layer thickness (m) & 1.7 & Calibrated \\
Light extinction coefficient in $2012\left(\mathrm{~m}^{-1}\right)$ & 0.2 & Calibrated \\
Light extinction coefficient in $2013\left(\mathrm{~m}^{-1}\right)$ & 0.5 & Calibrated \\
\hline
\end{tabular}

Table 4 Parameter values used in CAEDYM to simulate cyanobacteria concentration in 2012 and 2013

\begin{tabular}{|c|c|c|c|}
\hline Parameter (unit) & Parameter description & Assigned va & ues \\
\hline & & Microcystis & Aphanizomenon \\
\hline$\mu_{\max , i}\left(\right.$ day $\left.^{-1}\right)$ & Maximum potential growth rate at $20^{\circ} \mathrm{C}$ & 0.85 & 0.55 \\
\hline$I_{s, i}\left(\mu \mathrm{E} \mathrm{m}^{-2} \mathrm{~s}^{-1}\right)$ & Light saturation for maximum production & 550 & 250 \\
\hline$T_{s t d, i}\left({ }^{\circ} \mathrm{C}\right)$ & Standard temperature & 20 & 20 \\
\hline$T_{o p t, i}\left({ }^{\circ} \mathrm{C}\right)$ & Optimum temperature & 29 & 18 \\
\hline$T_{\max , i}\left({ }^{\circ} \mathrm{C}\right)$ & Maximum temperature & 40 & 28 \\
\hline$k_{r a, i}\left(\right.$ day $\left.^{-1}\right)$ & Respiration rate & 0.065 & 0.06 \\
\hline$\vartheta_{i}(-)$ & Constant for the loss rate & $1.03^{\mathrm{a}}$ & $1.08^{\mathrm{a}}$ \\
\hline$v_{i}\left(\mathrm{~m} \mathrm{~s}^{-1}\right)$ & Constant rising velocity & - & $510^{-7}$ \\
\hline$c_{4}\left(\mathrm{~m} \mathrm{~s}^{-1}\right)$ & $\begin{array}{l}\text { Coefficient for the light dependence of the } \\
\text { migration velocity }\end{array}$ & $1.410^{-4}$ & - \\
\hline$c_{5}\left(\mathrm{~m} \mathrm{~s}^{-1}\right)$ & Constant background settling velocity & $410^{-5}$ & - \\
\hline$K_{e p, i}\left(\mathrm{~m}^{-1} \cdot \mu \mathrm{g}^{-1} \mathrm{Chl} a \mathrm{~L}\right)$ & Specific light attenuation coefficient & 0.005 & 0.01 \\
\hline
\end{tabular}

Sources: ${ }^{a}$ Robson and Hamilton, 2004

\subsubsection{Indicators of model performance}

The root-mean-square error (RMSE), the coefficient of determination $\left(\mathrm{R}^{2}\right)$ and the mean absolute percentage error (MAPE) were used to evaluate the performance of the DyresmCaedym by measuring of the differences between values predicted by a model and the values actually observed. The RMSE, MAPE and $\mathrm{R}^{2}$ are calculated as the following:

$$
R M S E=\sqrt{\frac{\sum_{j=1}^{n}\left(X_{s i m, j}-X_{o b s, j}\right)^{2}}{n}}
$$




$$
\begin{gathered}
R^{2}=1-\frac{\sum_{j=1}^{n}\left(X_{s i m, j}-X_{o b s, j}\right)^{2}}{\sum_{j=1}^{n}\left(X_{o b s, j}-\bar{X}_{o b s}\right)^{2}} \\
M A P E=\frac{1}{n} \sum_{j=1}^{n}\left|\frac{X_{s i m, j}-X_{o b s, j}}{X_{o b s, j}}\right|
\end{gathered}
$$

where $X_{o b s, i}$ and $X_{s i m, j}$ are time-averaged observed values and simulated values at day $j$ and $\bar{X}_{o b s}$ is the mean of the observed data on the simulation period of $n$ days.

\section{Results}

We wanted to assess the performance of this simple model configuration to reproduce the succession between Microcystis aeruginosa and Aphanizomenon ovalisporum on two contrasted years and to understand the driving factor of each bloom.

\subsection{Water balance and temperature modelling}

The model was run separately on four successive years, from January $1^{\text {st }}$ to December 31 . It was calibrated with 2012 measurements and verified on 2010 and 2011 for water level and 2013 for water temperature. Simulations with the best performance were obtained for a maximum layer thickness of $1.7 \mathrm{~m}$, minimum layer thickness of $0.25 \mathrm{~m}$, vertical mixing coefficient of 2500 and a wind multiplication coefficient of 1.3 (Table 3). In 2010 and 2011 Secchi depth measurements were missing and the default value of $0.3 \mathrm{~m}^{-1}$ for the light extinction coefficient was used. In 2012, the light extinction coefficient was adjusted to $0.2 \mathrm{~m}^{-}$ ${ }^{1}$ and in 2013 to $0.5 \mathrm{~m}^{-1}$, consistent with Secchi depth average measurements in the reservoir. There were little or no rain events during the simulation period. This made the phytoplankton as the main factor affecting the light extinction coefficient.

The water level computed for the years 2010, 2011 and 2012 separately are presented in Figure 5. The water level variation was of about $25 \mathrm{~m}$ each year. The RMSEs were smaller than $1 \mathrm{~m}$ in each of the three years, $0.39 \mathrm{~m}$ on $2010,0.73 \mathrm{~m}$ on 2011 and $0.36 \mathrm{~m}$ on 2012. 


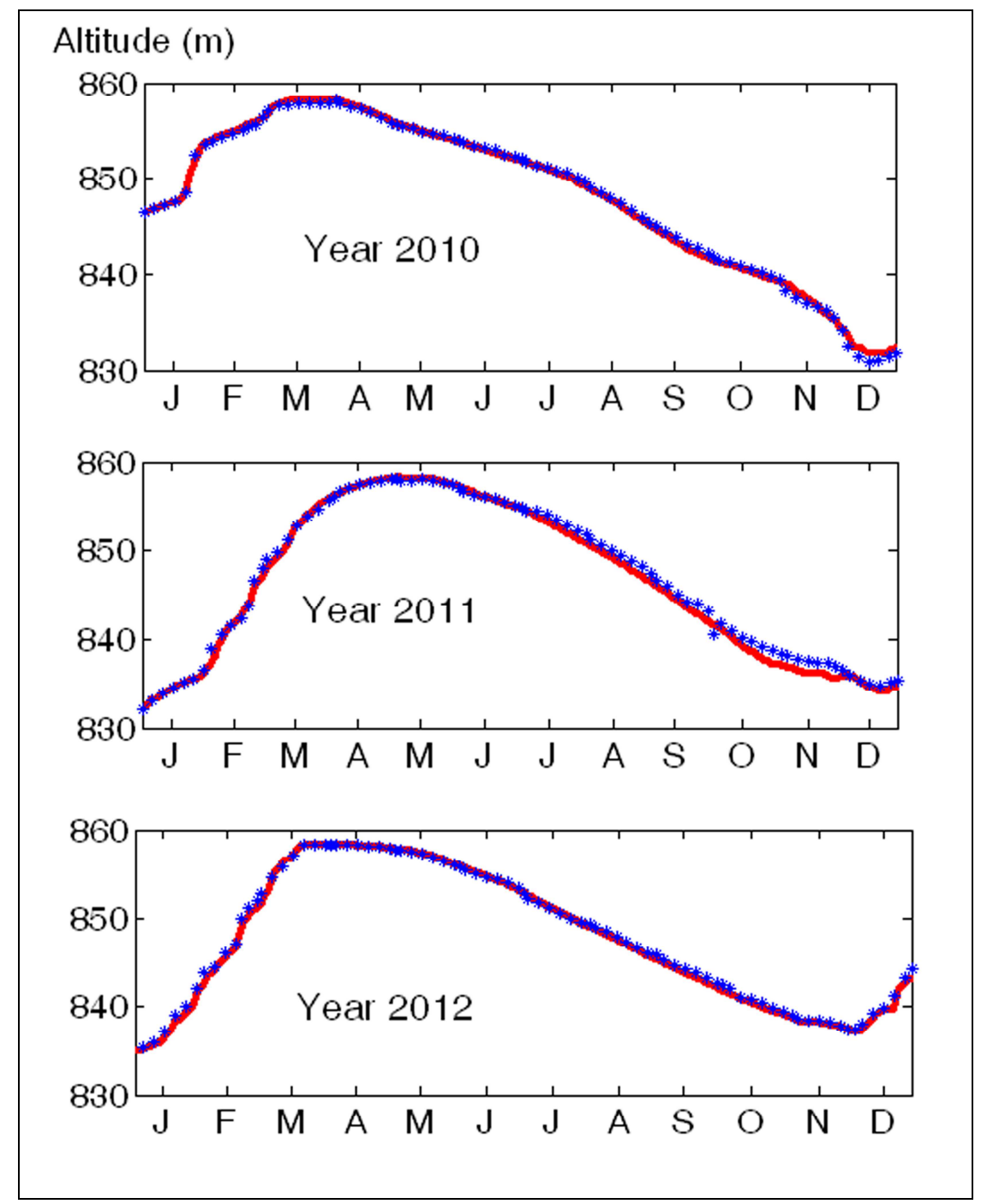

Figure 5 Simulated (red line) and observed (blue dots) water levels in Karaoun Reservoir in 2012 (model calibration), 2010 and 2011 (verification).

Regarding water temperature, in 2012 and 2013, good agreement was found between simulations and observations during both stratification and mixing periods (Figure 6, Table $5)$.

On Figure 6, model simulations and daily average vertical temperature profiles are compared every week of the simulation period in 2012, during both stratification and mixing periods. It shows how the model was able to localize the thermocline during the stratification period. However, the simulated thermocline spreads over lower temperatures and is steeper than the measured thermocline. The water temperatures simulated between 1 and $7 \mathrm{~m}$ depths were comparable to the observed temperatures with a RMSE less than $1{ }^{\circ} \mathrm{C}$ (Table 5). The lowest deviations between simulated and measured temperatures occurred at $19 \mathrm{~m}$ depth with a RMSE of $0.22{ }^{\circ} \mathrm{C}$. The highest discrepancies mainly occurred at the thermocline, between 10 and $16 \mathrm{~m}$, where the model underestimated temperatures $\left(0.8\right.$ to $\left.1.3^{\circ} \mathrm{C}\right)$. 


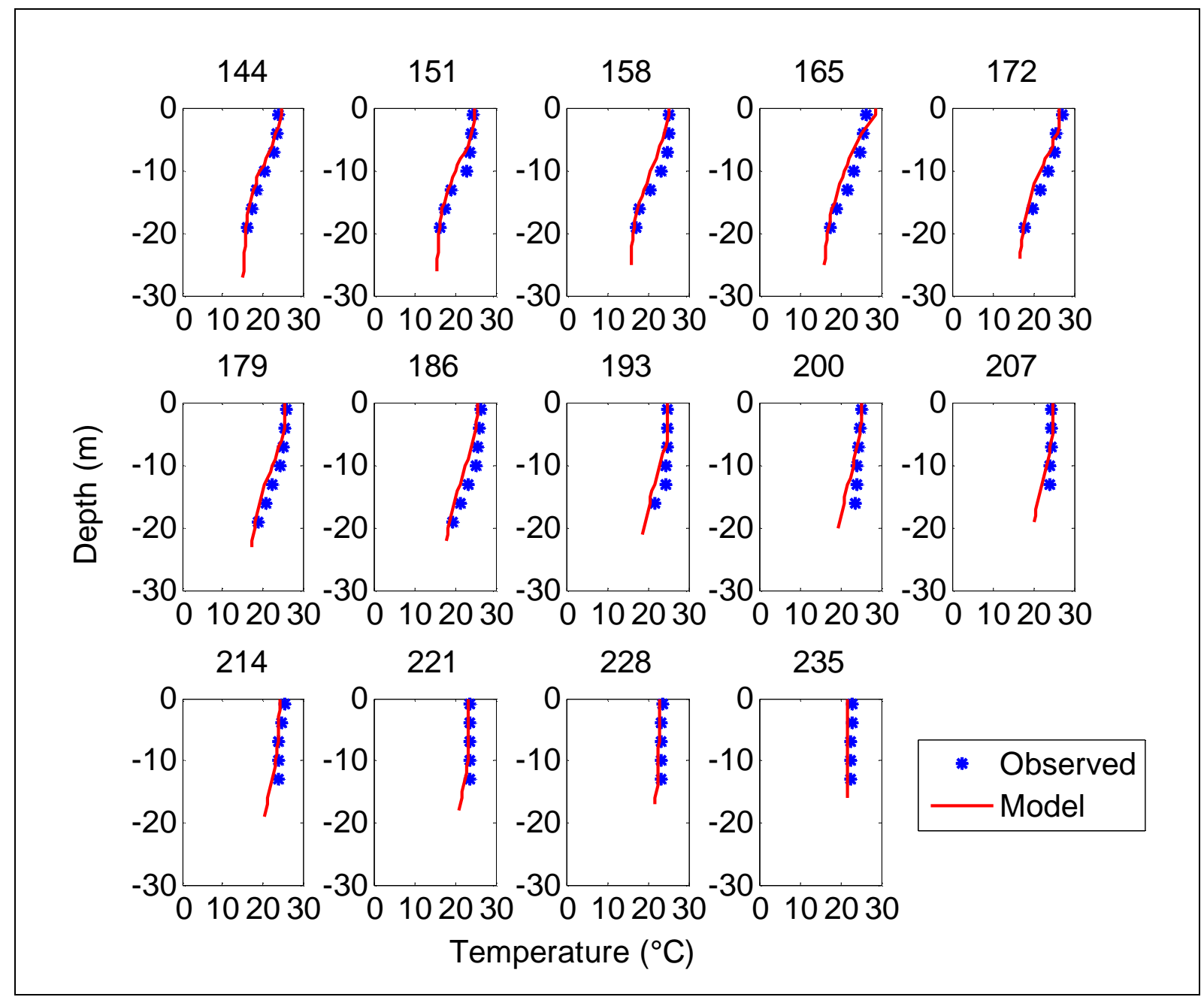

Figure 6 Measured (blue stars) and simulated (red line) daily average temperature profiles in Karaoun Reservoir in 2012 (dates in Julian days).

The model configuration was also verified on a 3-month period in 2013 covering an increase in water temperature, with the same parameter values as in 2012 (Figure 7). Good agreement was found between the simulated and the observed temperatures measurements (Table 5). RMSEs ranged from $0.63{ }^{\circ} \mathrm{C}$ at $16 \mathrm{~m}$ to $1.41{ }^{\circ} \mathrm{C}$ at $10 \mathrm{~m}$ (Table 5). The simulated water temperatures were overestimated at $1 \mathrm{~m}$ depth between 15 July and 15 August 2013 and underestimated at $7 \mathrm{~m}$ between 15 May and 30 July 2013. Highest discrepancies between simulated and measured temperature again occurred at the thermocline between 7 and $13 \mathrm{~m}$ depths.

The hydrodynamic model gave good results and could be used coupled with the biological model for cyanobacteria biomass simulations. 


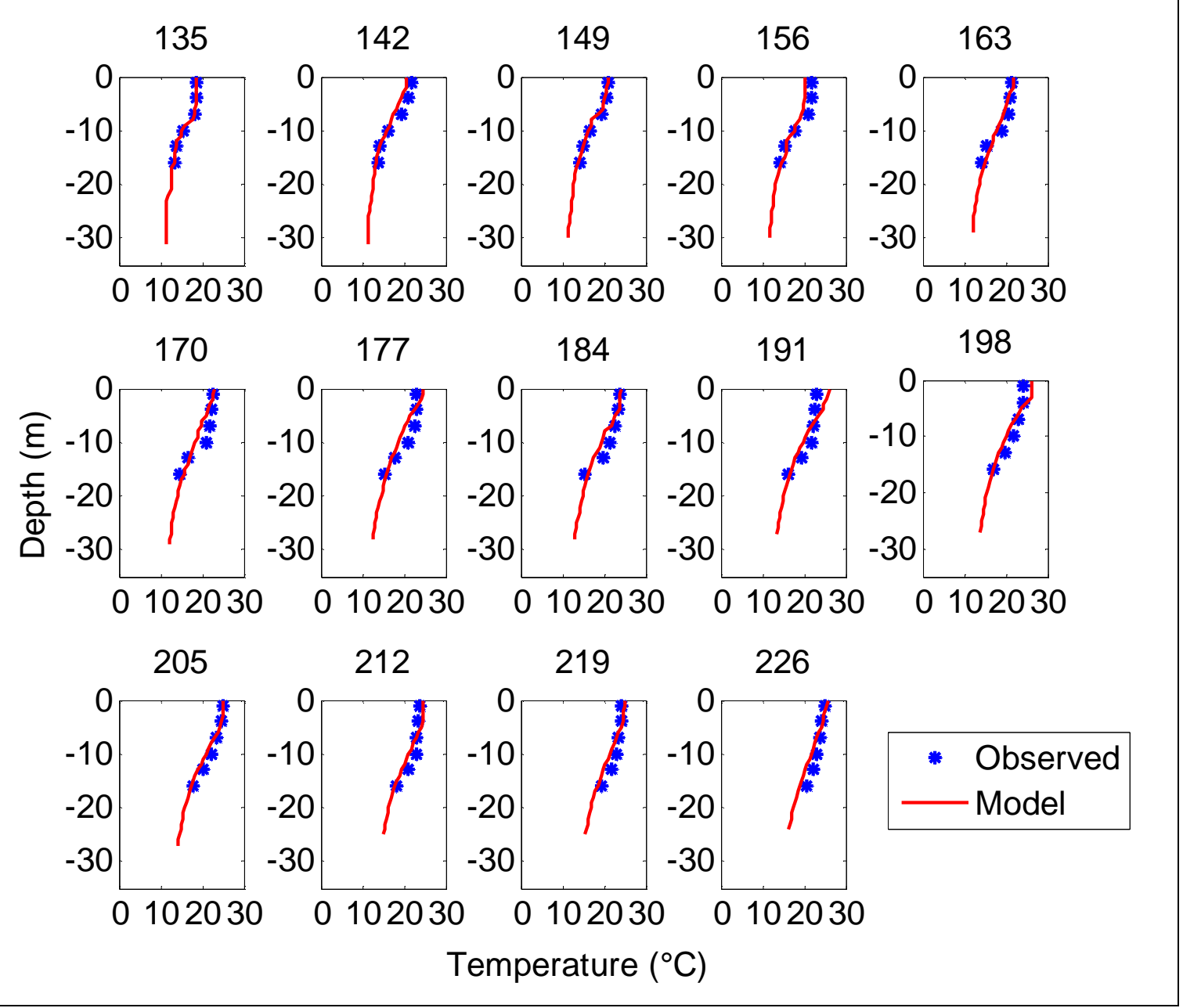

Figure 7 Observed (blue stars) and simulated (red line) daily average temperature profiles in Karaoun Reservoir in 2013 (dates in Julian days); profiles are represented at a time interval of one week.

Table 5 RMSE $\left({ }^{\circ} \mathrm{C}\right)$ and $\mathbf{R}^{2}$ between daily mean water temperature measurements and daily simulations at different depths in 2012 (24 May to 21 November 2012, 6 months) and 2013 (15 May to 21 August 2013, 3 months). (-): no measurements.

\begin{tabular}{|c|c|c|c|c|}
\hline & \multicolumn{2}{|c|}{ Year 2012 } & \multicolumn{2}{c|}{ Year 2013 } \\
\hline Depth & RMSE & $\mathrm{R}^{2}$ & RMSE & $\mathrm{R}^{2}$ \\
\hline $1 \mathrm{~m}$ & 0.86 & 0.94 & 1.28 & 0.85 \\
\hline $4 \mathrm{~m}$ & 0.63 & 0.97 & 0.79 & 0.93 \\
\hline $7 \mathrm{~m}$ & 0.96 & 0.95 & 1.11 & 0.94 \\
\hline $10 \mathrm{~m}$ & 1.33 & 0.89 & 1.41 & 0.96 \\
\hline $13 \mathrm{~m}$ & 1.21 & 0.91 & 1.02 & 0.97 \\
\hline $16 \mathrm{~m}$ & 0.78 & 0.99 & 0.63 & 0.96 \\
\hline $19 \mathrm{~m}$ & 0.22 & 0.99 & - & - \\
\hline
\end{tabular}

\subsection{Cyanobacterial seasonal succession modelling}

The model simulations were compared to biomass measurements at $1,5,10 \mathrm{~m}$ and to the average of the 3 depth measurements, hereafter called top $10 \mathrm{~m}$. 
In 2012, Aphanizomenon ovalisporum bloomed twice, in June and October while Microcystis aeruginosa bloomed once between August and September. The model was able to catch the first peak of Aphanizomenon ovalisporum biomass in June and the decrease between July and September with correct magnitude and timing between 1 and $10 \mathrm{~m}$ depth (Figure 8 and Figure 10). The model did not catch precisely the second Aphanizomenon bloom in October but it showed that Aphanizomenon ovalisporum biomass increased again between October and November. MAPE ranged between $19 \%$ at $1 \mathrm{~m}$ and $22 \%$ at $10 \mathrm{~m}$ depth (Table 6 ).

The simulated Microcystis aeruginosa biomass was comparable to the observed biomass at 1, 5, $10 \mathrm{~m}$ and in the top $10 \mathrm{~m}$ (Figure 8 and Figure 10), with low RMSE and high correlation $\left(R^{2}>0.85\right)$.

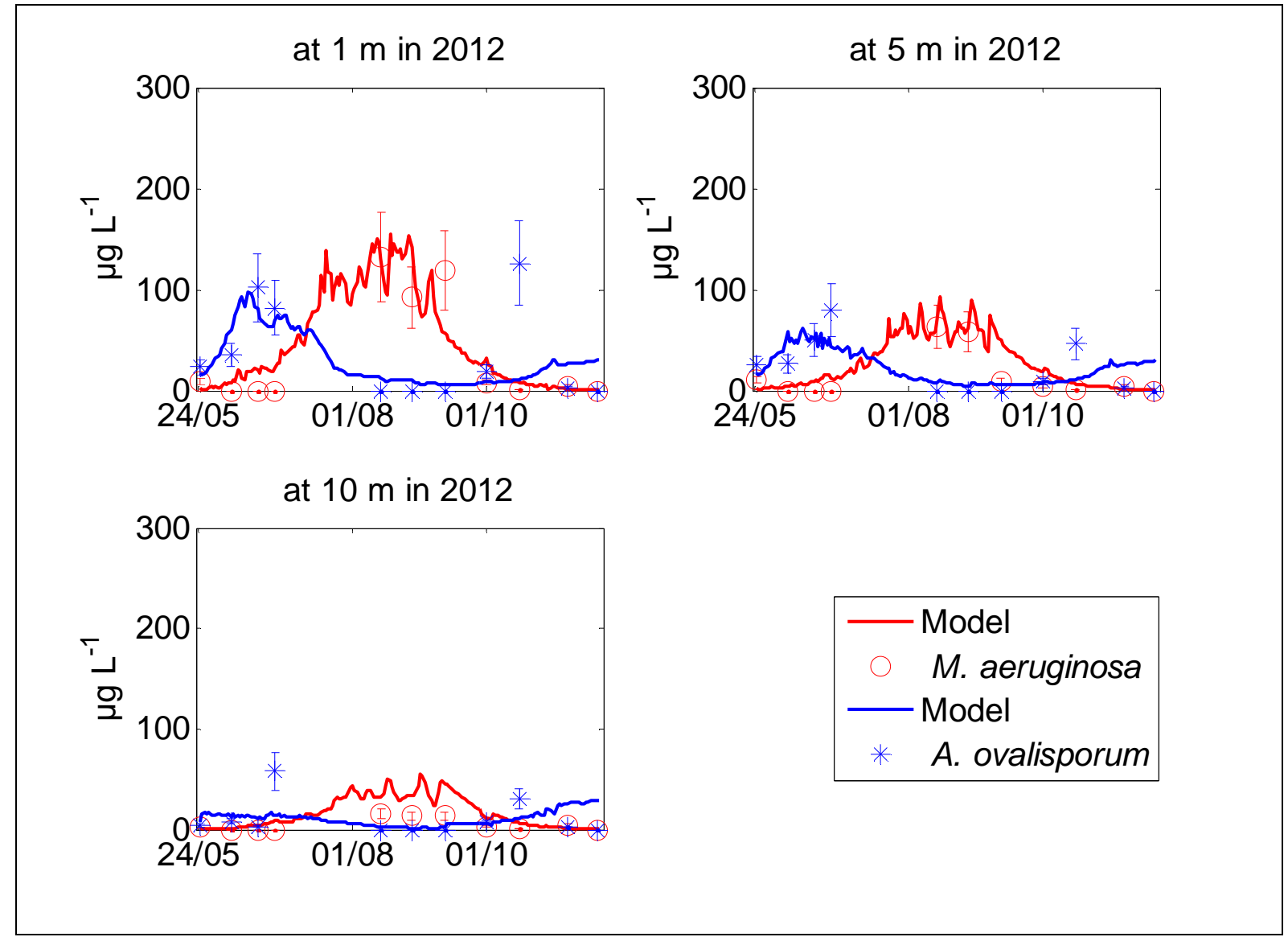

Figure 8 Observed (symbols) and modelled (lines) cyanobacterial concentrations at different depths in Karaoun Reservoir in 2012. Error bars represent the uncertainty on the conversion from phycocyanin to chlorophyll-a.

In 2013, the model showed good performance on the verification period that covered a Microcystis aeruginosa bloom in the absence of Aphanizomenon ovalisporum (Figure 9). The model was able to catch the low concentration of Aphanizomenon ovalisporum at $1,5,10 \mathrm{~m}$ (Figure 10 and Figure 9). The RMSE ranged between 0.4 and $5 \mu \mathrm{g} \mathrm{Chl} a \mathrm{~L}^{-1} . \mathrm{R}^{2}$ ranged between 0.43 at $10 \mathrm{~m}$ depth and 0.64 at $5 \mathrm{~m}$ depth. MAPE was around $25 \%$ (Table 6).

The model simulated the Microcystis aeruginosa bloom with correct magnitude and timing at $1 \mathrm{~m}$. However, it underestimated the Microcystis aeruginosa peak at the end of July 2013 at $5 \mathrm{~m}$ depth. The RMSE was low and ranged between 16 and $56 \mu \mathrm{g} \mathrm{Chl} a \mathrm{~L}^{-1} \cdot R^{2}$ ranged between 0.56 at $10 \mathrm{~m}$ depth 0.77 at $5 \mathrm{~m}$ depth. MAPE was around 20\% (Table 6). 

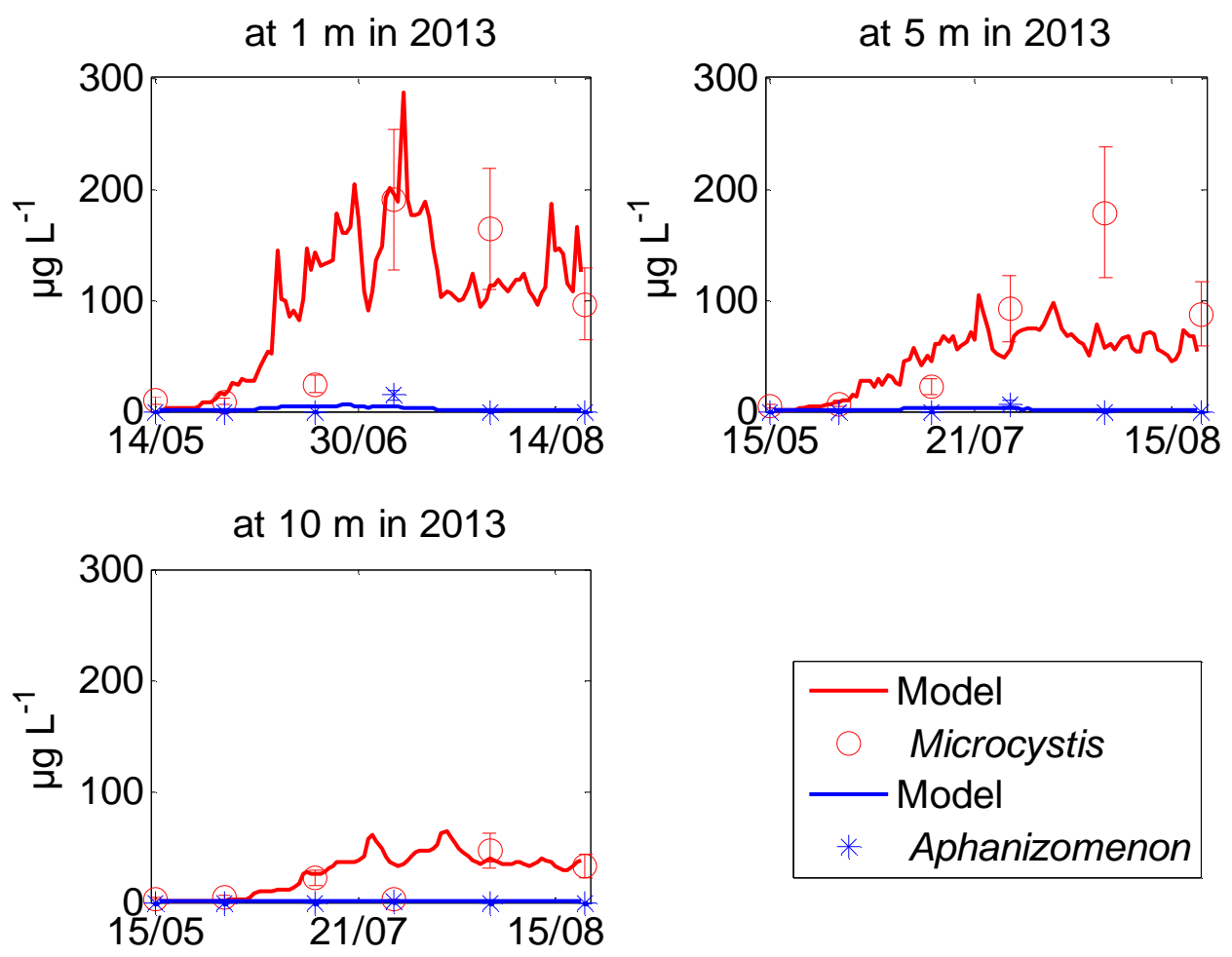

Figure 9 Observed (symbols) and modelled (lines) cyanobacterial succession at different depths in Karaoun Reservoir during 2013. Error-bars represent error from phycocyanin conversion to Chlorophyll-a.

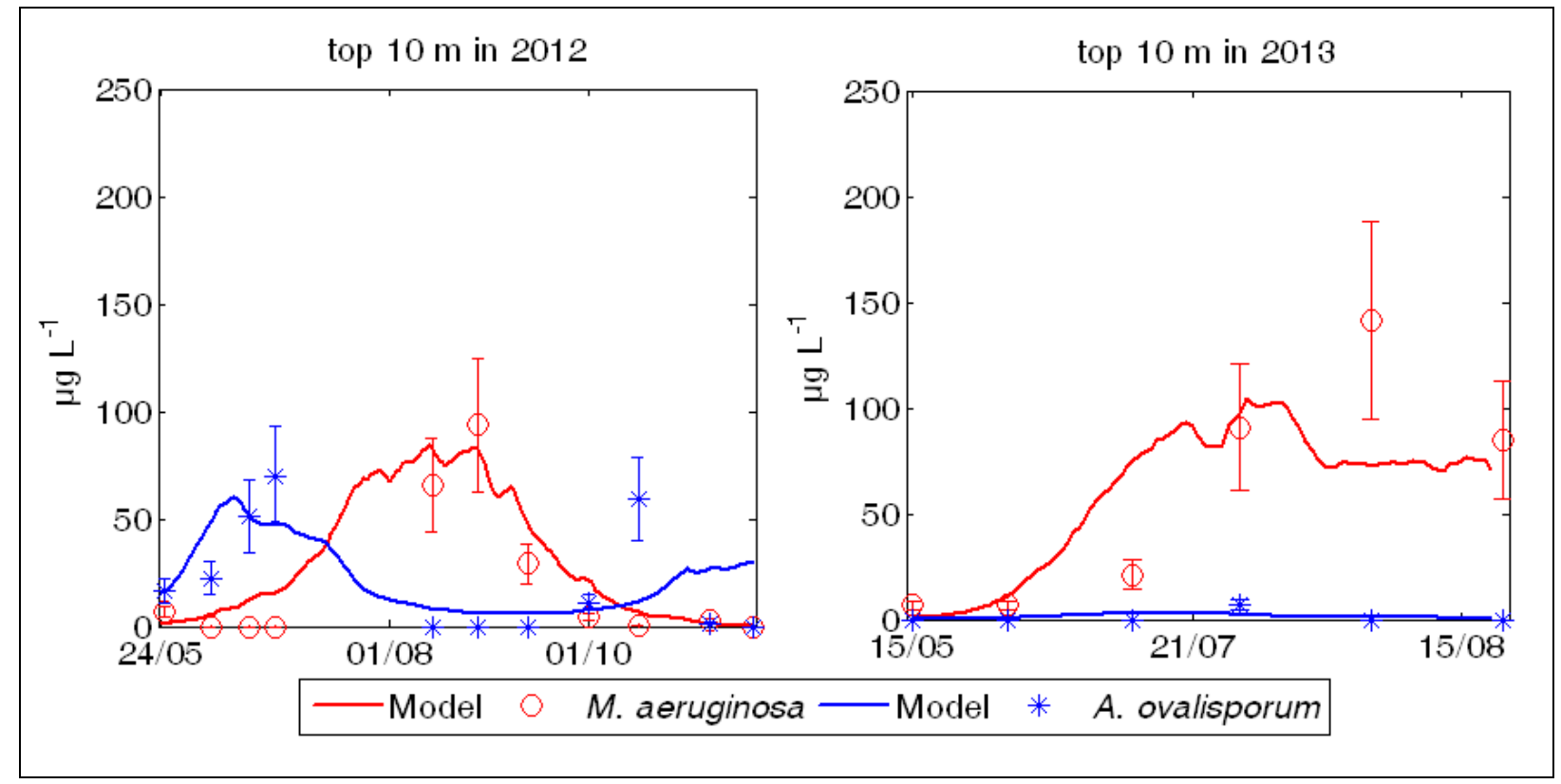

Figure 10 Observed (symbols) and modelled (lines) cyanobacterial succession averaged over the top 10m in Karaoun Reservoir in 2012 and 2013. Error-bars represent error from phycocyanin conversion to Chlorophyll-a. 
Table 6 RMSE ( $\mu$ g Chl $a$ L-1), MAPE ( $\%$ ) and $\mathbf{R}^{2}$ between cyanobacterial biomass measurements and simulations at different depth in 2012 (24 May to 21 November 2012, 6 months) and 2013 (15 May to 21 August 2013, 3 months).

\begin{tabular}{|c|c|c|c|c|c|c|c|c|c|c|c|c|}
\hline & \multicolumn{6}{|c|}{ Year 2012} & \multicolumn{6}{|c|}{ Year 2013} \\
\hline & \multicolumn{3}{|c|}{ M. aeruginosa } & \multicolumn{3}{|c|}{ A. ovalisporum } & \multicolumn{3}{|c|}{ M. aeruginosa } & \multicolumn{3}{|c|}{ A. ovalisporum } \\
\hline & $\begin{array}{l}\text { RMSE } \\
\mu \mathrm{g} \mathrm{L}^{-1}\end{array}$ & $\mathrm{R}^{2}$ & $\begin{array}{c}\text { MAPE } \\
\%\end{array}$ & $\begin{array}{l}\text { RMSE } \\
\mu \mathrm{g} \mathrm{L}^{-1}\end{array}$ & $\mathrm{R}^{2}$ & $\begin{array}{c}\text { MAPE } \\
\%\end{array}$ & $\begin{array}{l}\text { RMSE } \\
\mu \mathrm{g} \mathrm{L}^{-1}\end{array}$ & $\mathrm{R}^{2}$ & $\begin{array}{c}\text { MAPE } \\
\%\end{array}$ & $\begin{array}{l}\text { RMSE } \\
\mu \mathrm{g} \mathrm{L}^{-1}\end{array}$ & $\mathrm{R}^{2}$ & $\begin{array}{c}\text { MAPE } \\
\%\end{array}$ \\
\hline $1 \mathrm{~m}$ & 26 & 0.87 & 14 & 38 & 0.50 & 19 & 56 & 0.69 & 22 & 0.4 & 0.53 & 25 \\
\hline $5 \mathrm{~m}$ & 14 & 0.86 & 19 & 21 & 0.66 & 21 & 56 & 0.77 & 24 & 5 & 0.43 & 27 \\
\hline $10 \mathrm{~m}$ & 13 & 0.91 & 58 & 18 & 0.07 & 22 & 16 & 0.56 & 24 & 2.5 & 0.64 & - \\
\hline Top 10m & 12 & 0.94 & 11 & 21 & 0.56 & 22 & 38 & 0.66 & 19 & 2 & 0.5 & 27 \\
\hline
\end{tabular}

\subsection{Controlling factors of the succession between Aphanizomenon ovalisporum and Microcystis aeruginosa according to Dyresm- Caedym}

The dynamics and succession between cyanobacterial species was assessed by analysing the time evolution of the growth rate, light and temperature limiting factors at $1 \mathrm{~m}$ depth (Figure 11 and Figure 12). In late May 2012, Aphanizomenon ovalisporum initial concentration was about $35 \mu \mathrm{g} \mathrm{Chl} a \mathrm{~L}^{-1}$ while Microcystis aeruginosa was much smaller, less than $5 \mu \mathrm{g}$ Chl $a$ $\mathrm{L}^{-1}$ (Figure 11).

According to the model, in May and June 2012, Aphanizomenon ovalisporum was not limited by temperature and moderately limited by light and its production was high $\left(0.55\right.$ day $\left.^{-1}\right)$. This resulted in an increase in its concentration to about $100 \mu \mathrm{g} \mathrm{Chl} a \mathrm{~L}^{-1}$ in mid June. Between mid June and mid September 2012, stronger limitation by temperature accompanied with periods of light limitation resulted in a continuous decrease in Aphanizomenon ovalisporum concentration down to $10 \mu \mathrm{g} \mathrm{Chl} a \mathrm{~L}^{-1}$ in mid September 2012. Aphanizomenon ovalisporum then increased again to $25 \mu \mathrm{g} \mathrm{Chl} a \mathrm{~L}^{-1}$ in the end of October 2012 when water temperature became favourable (Figure 11). 


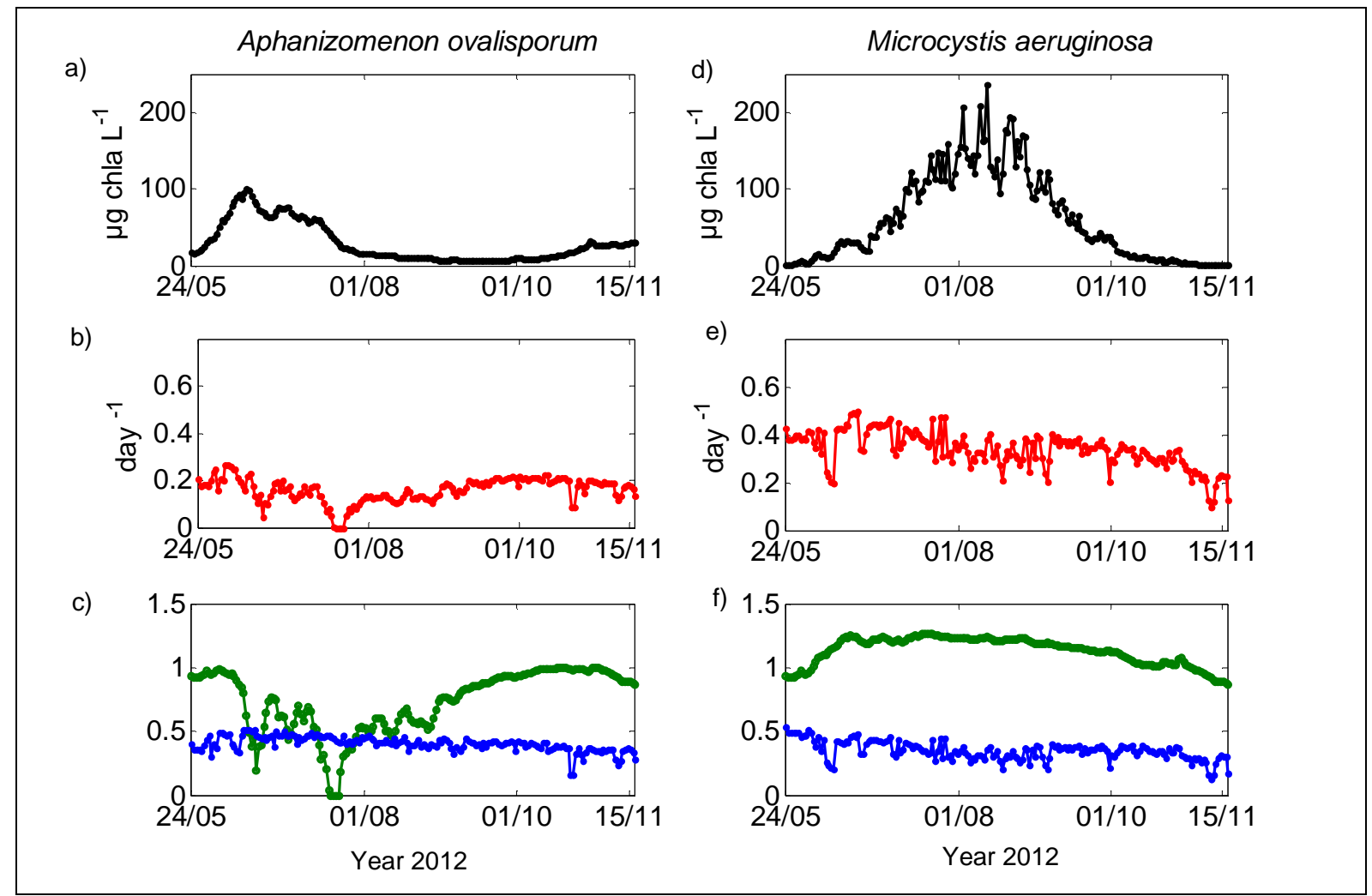

Figure 11 Variation of a) Aphanizomenon ovalisporum daily average biomass b) its growth rate c) temperature (green) and light (blue) limitation at $\mathbf{1} \mathbf{~ m}$ and d) Microcystis aeruginosa daily average biomass e) its growth rate f) temperature (green) and light (blue) limitation at $1.5 \mathrm{~m}$ in 2012 as explained by caedym.

Regarding Microcystis aeruginosa, from the end of May to the beginning of June 2012, it was not limited by temperature and moderately limited by light. This allowed an increase in its production (Figure 11) up to around $150 \mu \mathrm{g} \mathrm{Chl} a \mathrm{~L}^{-1}$ at the end of August 2012. M. aeruginosa then continuously decreased to less than $5 \mu \mathrm{g} \mathrm{Chl} a \mathrm{~L}^{-1}$ when temperature became less favourable between September and October 2012 (Figure 11).

Higher initial concentration of Aphanizomenon ovalisporum at the beginning of the simulation allowed it to dominate in June 2012. Although Microcystis aeruginosa has a higher growth rate, it reaches a maximum concentration only in August because of very low initial concentration. At the end of June 2012, the increase of Microcystis aeruginosa coincided with the decline of Aphanizomenon ovalisporum. 


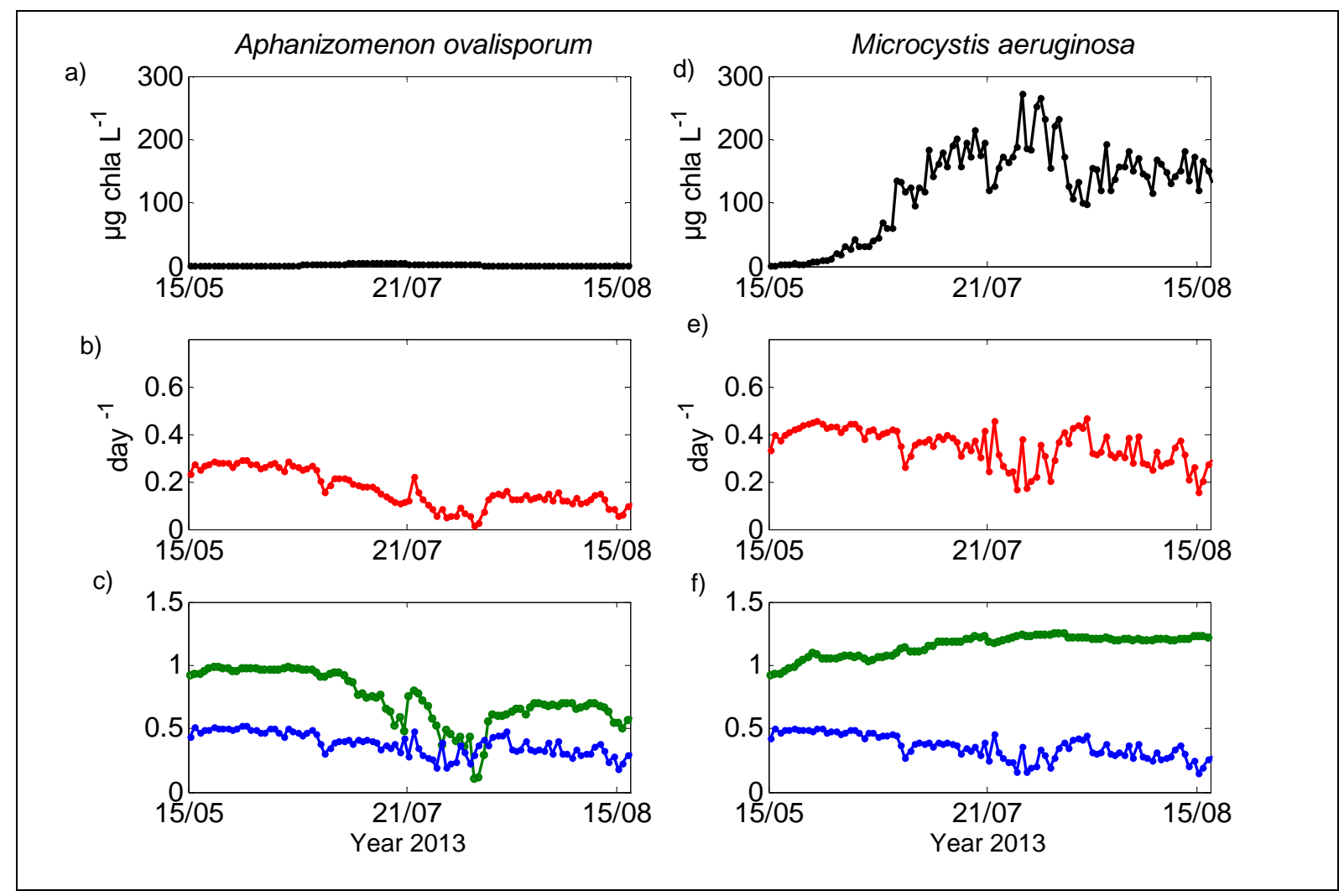

Figure 12 Variation of a) Aphanizomenon ovalisporum daily average biomass b) its growth rate c) temperature (green) and light (blue) limitation at $1 \mathrm{~m}$ and d) Microcystis aeruginosa daily average biomass e) its growth rate f) temperature (green) and light (blue) limitation at $1.5 \mathrm{~m}$ in $\mathbf{2 0 1 3}$

At the beginning of June 2013, both cyanobacteria concentrations were below $3 \mu \mathrm{g}$ Chl $a \mathrm{~L}^{-1}$. The higher maximum growth rate of Microcystis aeruginosa resulted in its dominance under favourable temperature and light conditions. The lower growth rate of Aphanizomenon ovalisporum did not permit it to keep up with Microcystis aeruginosa, it reached a very low maximum value of $5 \mu \mathrm{g} \mathrm{Chl} a \mathrm{~L}^{-1}$ (mid July 2013), then nearly vanished (Figure 12).

\section{Discussion}

\subsection{Model performance for water balance and water temperature}

Dyresm-Caedym model simulations of water level, water temperature and cyanobacterial biomass were satisfactory. Differences between simulated and observed water levels ranged between 0.4 and $0.7 \mathrm{~m}$ during the study period. The good performance for simulating accurately the reservoir water balance and water level fluctuation is a strength of the model. In arid regions like the Middle-East, during severe droughts, the water level can drop to critical depths due to intense use. A good prediction of the water level is mandatory for tackling the water crisis and developing efficient emergency plans (Kozhevnikova \& Shveikina, 2014). Water level fluctuations, caused by monsoonal climate and artificial drawdown can alter the hydrological conditions and influence light and nutrient availability, influencing phytoplankton succession (Tian et al. 2015). The decrease in water level can indirectly affect the physical-chemical and biological characteristics of freshwater bodies, mainly through mixing enhancement (Valdespino-Castillo et al. 2014). Extreme decreases in reservoir water level can affect the thermal structure of the water column (Zohary and 
Ostrovsky 2011). The amount of energy required to mix the water column increases as the water level increases (Kling 1988). The increase in maximum depth of Lake Elsinore from 5 to $10.5 \mathrm{~m}$ increased the stability of its water column by four times (Lawson and Anderson 2007).

The model simulated changes in water level with good precision (error less than $1 \mathrm{~m}$ for an annual variation of $25 \mathrm{~m}$ ) even though the data entered into the model were not complete. They did not include the leakage discharges through Karaoun dam, ground water seepage, and additional inflows by springs at the bottom of Karaoun. The error due to evaporation is minor; calculated evaporation in summer was negligible in comparison to inflow and withdrawals (Fadel et al., 2014b). Also, several field and technical errors could have increased the RMSE. Technical errors made during the construction of the bathymetric map may be another cause of uncertainty. With an imprecise geometry, the model is not able to represent precisely the physical processes of transport and mixing (Rigosi and Rueda, 2012).

The RMSE of simulated water temperature at different depths ranged between 0.2 and $1.4{ }^{\circ} \mathrm{C}$. The thermal model performance was mostly comparable to, and sometimes better than, previously published applications of Dyresm. RMSEs of $1.4{ }^{\circ} \mathrm{C}$ and $0.9^{\circ} \mathrm{C}$ were reported in the epilimnion and hypolimnion of Lake Ravn, Denmark (Trolle et al., 2008); $0.48{ }^{\circ} \mathrm{C}$ in El Gergal reservoir, Spain (Rigosi et al., 2011); around $1{ }^{\circ} \mathrm{C}$ at surface and bottom in Lake Kinneret (Gal et al., 2003) and $2{ }^{\circ} \mathrm{C}$ at the bottom of Lake Pusiano, Italy (Copetti et al., 2006) and $2{ }^{\circ} \mathrm{C}$ as well in Clearwater Lake, Canada (Tanentzap et al., 2007).

The differences between the model simulations and observed measurements can be attributed to the following factors: meteorological data measured at a $40 \mathrm{~km}$ far station, errors in observed measurements, and the one-dimensionality of Dyresm-Caedym.

Errors made while noting water level values at the graduated spillway could have also increased the RMSE. A $1 \mathrm{~cm}$ error for a reservoir of $12 \mathrm{~km}^{2}$ corresponds to an average daily inflow of $1.5 \mathrm{~m}^{3} \mathrm{~s}^{-1}$. This error can increase up to $5 \mathrm{~cm}$ due to waves during windy weather.

Some deviations exist between simulated and observed water temperatures. At certain depths, the water temperature was underestimated for a period of a month then overestimated in the following month. Another marked deviation is the underestimation of water temperature at higher depths $(13,16$ and $19 \mathrm{~m})$, which can be related to the position of the sensor chain at the spillway, in a region where the water depth is by several meters shallower than in the modelled area, the deepest part of the reservoir. The thermocline is known to be shallower close to the banks than in the middle of a lake (Lampert and Sommer 2007).

Intense winds can destroy the thermal stratification, homogenize the water column and decrease surface cyanobacterial biomass (Zhou et al. 2015; Huisman et al. 2004). Inaccuracies in wind speed, due to the $40-\mathrm{km}$ distance between the weather station and the lake, could have resulted in some deviations between simulations and observed cyanobacteria biomasses. A similar observation of temperature overestimation at the surface and underestimation in the deep layer between 10 and $30 \mathrm{~m}$ was reported in Lake Constance and attributed due to a lack in diffusion in the hypolimnion and metalimnion in the model (Hornung, 2002). In Karaoun Reservoir, simulated water temperatures were highly underestimated at the beginning of the calibration period. Temperature measurements were taken at the spillway, near the outlet. The total discharge capacity of this outlet can result in mixing that increase water temperature at bottom layers. The introduction of a wind multiplication factor and the increase of the vertical 
mixing coefficient highly improved our simulations by increasing heat diffusion to the deep layers. The default value of vertical mixing coefficient in the model is 200 . However, this coefficient can range from 1 to 7200 depending on the geometry of the lake (Hornung, 2002). A value of 1000 was adopted for Lake Constance (Rinke et al., 2010), 200 for Lake Kinneret (Gal et al., 2003), 400 for Lake Rotorua (Burger et al., 2008) and 7200 for Sau Reservoir (Takkouk and Casamitjana 2015). A vertical mixing coefficient of 2500 worked best for Karaoun Reservoir, within the range of experimental values estimated in field studies (Yeates and Imberger, 2003). More details about the vertical mixing coefficient are presented in Yeates and Imberger (2003) and Hornung (2002).

\subsection{Model performance for cyanobacterial biomasses}

The model succeeded in capturing the main patterns of Microcystis aeruginosa and the cyanobacterial succession in Karaoun reservoir in 2012 and 2013. Looking at the growth rate of both cyanobacteria species and their limitation factors helped us in identifying the driving factors of the cyanobacterial succession. Between mid-May and mid-September 2012, A. ovalisporum is limited by high water temperature $\left(>24^{\circ} \mathrm{C}\right)$ (Fadel et al., 2014a). Temperature can become damaging if it exceeds the optimal temperature for cyanobacterial growth (Rigosi et al., 2015). In laboratory conditions, optimal temperature is around $29^{\circ} \mathrm{C}$ for most cyanobacteria (Lürling et al. 2013). Unlike other Mediterranean lakes where blooms of $A$. ovalisporum are observed when water temperature is around $25^{\circ} \mathrm{C}$ (Gkelis et al., 2005; Pollingher, 1998), in Lake Karaoun, A. ovalisporum is able to grow at lower temperatures (around $22^{\circ} \mathrm{C}$ ). Water temperatures higher than $25^{\circ} \mathrm{C}$ allowed Microcystis aeruginosa to outgrow Aphanizomenon ovalisporum.

Dyresm-Caedym was already applied to simulate cyanobacterial succession, in Lake Kinneret (Gal et al., 2009). However, Caedym configuration was highly complex and contained many parameters to simulate not only phytoplankton but also nutrients, dissolved oxygen, $\mathrm{pH}$, zooplankton and bacteria. The simulation period was much longer than ours, about 7 years. The model succeeded in simulating annual variations of cyanobacterial species. The coefficients of determination for the concentrations averaged over the top $10 \mathrm{~m}$ were 0.31 for Microcystis and 0.50 for Aphanizomenon, lower than in our application with simplified Caedym processes: 0.66 to 0.94 for Microcystis and 0.50 to 0.56 for Aphanizomenon (Table 6).

Phytoplankton represents an important feeding source for many herbivores that inhabit water bodies as the zooplankton, zebra mussels and planktivorous fish. Grazing can cause a loss in the phytoplankton groups including cyanobacteria (Wang et al., 2010; Zhang et al., 2009). The effect of zooplankton grazing on cyanobacterial biomass was partly compensated in the model by increasing the loss rate, but this is not sufficient as zooplankton biomass and grazing rate vary greatly with time and can affect cyanobacteria biomass. The average size of Microcystis aeruginosa in Karaoun reservoir is $600 \mu \mathrm{m}$. Large-sized Daphina can consume small-sized Microcystis colonies with a diameter generally less than $50 \mu \mathrm{m}$ but they have difficulties in ingesting large sized colonies. The ingestion rate of Microcystis aeruginosa depends on the duration of the application of Daphnia, presence of microcystin toxin (Zhu et al. 2015), and the presence of fish that affect the process of grazing (Sarnelle, 2007).

Dyresm-Caedym is a one-dimensional model which considers only vertical variation of temperature and phytoplankton biomass, supposed to be constant on the horizontal. A 
decrease or increase in cyanobacterial biomass resulting from horizontal transport is not taken into account by the model. Humphries and Lyne (1988) found that high rising velocities of Microcystis aeruginosa could concentrate them near the surface, and favour scum formation and thus losses from wind-driven advection to the edges. Visible scums at the edges of Karaoun Reservoir were previously reported by Atoui et al. (2013).

Another cause of discrepancy between simulations and measurements can be an error in the measurements. We use the phycocyanin probe to perform field measurements and compare them to model simulations. The used phycocyanin probe has a background noise of $0.6 \mu \mathrm{g}$ phycocyanin $\mathrm{L}^{-1}$ (Bastien et al., 2011). The phycocyanin probe measures phycocyanin fluorescence and not the cyanobacteria concentration, expressed in chlorophyll-a in model simulations. Phycocyanin measurements are then converted to chlorophyll-a using a constant phycocyanin to chlorophyll-a conversion ratio, in order to be compared with simulated cyanobacteria biomass. The phycocyanin to chlorophyll-a ratio in cyanobacterial cells varies with the physico-chemical characteristics of the growth medium (Foy, 1993). While phycocyanin probe measurements cause minor discrepancies, errors due to conversion of phycocyanin can result in major discrepancies between simulations and measurements.

The selected time periods for model calibration and validation started in Spring and did not include winter season. The model may not be able to describe the evolution of the cyanobacteria biomass in winter. High discrepancies between the model and the cyanobacteria biomass measurements were observed in Autumn, as shown in Figure 8, for Aphanizomenon ovalisporum which might be due to N:P ratio. The model cannot precisely simulate cyanobacteria concentration in winter due to some processes that are not included, like the formation of resting spores. However, the model importance is in its ability to predict the biomass and the succession between cyanobacteria species in Spring-Summer period. TN:TP ratio did not exceed 22:1 during the study period (Fadel 2014). According to Smith et al. (1995), lake water TN:TP ratios below 22:1 can favour the dominance of N2-fixing cyanobacteria. However, the role of this ratio is minor in controlling the succession of both cyanobacteria in our study due to continuous availability of nutrients for both species and major control by other factors like light and water temperature. Even if the N:P ratio would favour the dominance of N2-fixing cyanobacterium A. ovalisporum, it cannot overcome $M$. aeruginosa due to a major controlling factor, water temperature. M. aeruginosa outcompetes A. ovalisporum whenever water temperature rises above $22{ }^{\circ} \mathrm{C}$.

Management of freshwater bodies to improve their quality is one of the main uses of such hydrodynamic-ecological models. However, large data set required by complex models can complicate such objective. Most of the recently published articles on ecological modelling covered used complex models to simulate phytoplankton blooms (Bruce et al., 2006; Gal et al., 2009). However, Complex models do not necessarily improve the precision of simulated variables (Barbara and Robson 2014). Complex models usually have fewer restricting assumptions and exhibit more flexibility; however, increasing the level of complexity in the model leads to an increased sensitivity of the output to the input (Paudel and Jawitz 2012). Due to the complexity of these systems, such models are often elaborate and include a large number of estimated parameters. However, correspondingly large data sets are rarely available for calibration purposes, leading to models that may be overfit and possess reduced predictive capabilities. Mcdonald and urban 2010 demonstrated that increasing the complexity of phytoplankton biomass model tend to produce a better model fit to calibration data, but beyond a certain degree of complexity the benefits of adding parameters are diminished and therefore the risk of overfitting becomes greater. The results of our study showed that simple 
model can successfully simulate succession of cyanobacteria based on few essential processes.

The simplified model presented in this paper will be used by the local managers of Karaoun Reservoir. It can help them in diagnosing problems and evaluating alternative solutions for maintaining the water quality. It can be used for the assessment of the feasibility of the different management actions in different contexts before major investments in infrastructure are considered.

\section{Conclusion}

Unlike most complex model configurations that simulate total chlorophyll concentrations or test scenarios, in this study, a simplified version of Dyresm-Caedym was applied to simulate the succession between cyanobacterial species in a eutrophic reservoir with high water level variations. Dyresm simulated variations of water level and water temperature with high precision. A simplified Caedym configuration, based on water temperature, light limitation and cyanobacteria vertical migration governed by light only simulated cyanobacterial succession and biomass with correct magnitude and timing.

The model results suggest that higher maximum production of Microcystis aeruginosa during favourable temperature and light conditions allowed it to outgrow Aphanizomenon ovalisporum despite lower initial concentration. This modelling approach could be transposed to other eutrophic Mediterranean lakes and reservoirs to describe the competition between dominant phytoplankton species, to contribute to early warning systems or to be used to predict the impact of climate change and management.

\section{References}

Akomeah, Eric, Kwok Pan Chun, and Karl-Erich Lindenschmidt. 2015. Dynamic Water Quality Modelling and Uncertainty Analysis of Phytoplankton and Nutrient Cycles for the Upper South Saskatchewan River. Environmental Science and Pollution Research 22 (22): 18239-51.

Asaeda, T., Pham, H.S., Nimal Priyantha, D.G., Manatunge, J., Hocking, G.C., 2001. Control of algal blooms in reservoirs with a curtain: a numerical analysis. Ecological Engineering 16, 395-404.

Atoui, A., Hafez, H., Slim, K., 2013. Occurrence of toxic cyanobacterial blooms for the first time in Lake Karaoun, Lebanon. Water and Environment Journal 27, 42-49.

Bastien, C., Cardin, R., Veilleux, E., Deblois, C., Warren, A., Laurion, I., 2011. Performance evaluation of phycocyanin probes for the monitoring of cyanobacteria. Journal of Environmental Monitoring 13, 110-118.

Bruce, L.C., Hamilton, D., Imberger, J., Gal, G., Gophen, M., Zohary, T., Hambright, K.D., 2006. A numerical simulation of the role of zooplankton in $\mathrm{C}, \mathrm{N}$ and $\mathrm{P}$ cycling in Lake Kinneret, Israel. Ecological Modelling 193, 412-436.

Burger, D.F., Hamilton, D.P., Pilditch, C.A., 2008. Modelling the relative importance of internal and external nutrient loads on water column nutrient concentrations and phytoplankton biomass in a shallow polymictic lake. Ecological Modelling 211, 411-423.

Callieri, C., Bertoni, R., Contesini, M. \& Bertoni, F., 2014. Lake Level Fluctuations Boost Toxic Cyanobacterial "Oligotrophic Blooms". PLoS ONE 9, e109526.

Copetti, D., Tartari, G., Morabito, G., A. Oggioni, E.L.a.J.I., 2006. A biogeochemical model of Lake Pusiano (North Italy) and its use in the predictability of phytoplankton blooms: first preliminary results. Journal of Limnology 65, 59-64. 
Cui, Y., Zhu, G., Li, H., Luo, L., Cheng, X., Jin, Y., \& Trolle, D., 2016. Modeling the response of phytoplankton to reduced external nutrient load in a subtropical Chinese reservoir using DYRESMCAEDYM. Lake and Reservoir Management, 32(2), 146-157.

Fadel, A., Atoui, A., Lemaire, B., Vinçon-Leite, B., Slim, K., 2014a. Dynamics of the toxin cylindrospermopsin and the cyanobacterium Chrysosporum (Aphanizomenon) ovalisporum in a Mediterranean eutrophic reservoir. Toxins 6, 3041-3057.

Fadel, A., Lemaire, B.J., Atoui, A., Vinçon-Leite, B., Amacha, N., Slim, K., Tassin, B., 2014b. First assessment of the ecological status of Karaoun Reservoir, Lebanon. Lakes \& Reservoirs: Research \& Management 19, 142-157.

Fadel, A. (2014). Physico-chemical functioning and development of phytoplankton in Karaoun reservoir (Lebanon): application of a hydrodynamic-ecological model (Doctoral dissertation, Université Paris-Est).

Fadel, A., Atoui, A., Lemaire, B. J., Vinçon-Leite, B., \& Slim, K., (2015). Environmental factors associated with phytoplankton succession in a Mediterranean reservoir with a highly fluctuating water level. Environmental monitoring and assessment, 187(10), 1-14.

Fadel, A., Faour, G., \& Slim, K., (2016). Assessment of the trophic state and chlorophyll-a concentrations using Landsat OLI in Karaoun reservoir, Lebanon. Lebanese Science Journal, 17(2), 130.

Foy, R.H., 1993. The phycocyanin to chlorophyll-a ratio and other cell components as indicators of nutrient limitation in two planktonic cyanobacteria subjected to low-light exposures. Journal of Plankton Research 15, 1263-1276.

Gal, G., Hipsey, M.R., Parparov, A., Wagner, U., Makler, V., Zohary, T., 2009. Implementation of ecological modeling as an effective management and investigation tool: Lake Kinneret as a case study. Ecological Modelling 220, 1697-1718.

Gal, G., Imberger, J., Zohary, T., Antenucci, J., Anis, A., Rosenberg, T., 2003. Simulating the thermal dynamics of Lake Kinneret. Ecological Modelling 162, 69-86.

Gkelis, S., Moustaka-Gouni, M., Sivonen, K. \& Lanaras, T., 2005. First report of the cyanobacterium Aphanizomenon ovalisporum Forti in two Greek lakes and cyanotoxin occurrence. Journal of Plankton Research 27, 1295-1300.

Hamilton, D.P., Schladow, S.G., 1997. Prediction of water quality in lakes and reservoirs. Part I. Model description. Ecological Modelling 96, 91-110.

Hipsey, M.R., 2007. Water quality modelling of west Seti hydropower reservoir using DYRESMCAEDYM. The university of Western australia, Australia.

Hornung, R., 2002. Numerical modelling of stratification in Lake Constance with the 1-D hydrodynamic model DYRESM. Master Thesis, University of Stuttgart, Germany.

Huisman, J., Sharples, J., Stroom, J.M., Visser, P.M., Kardinaal, W.E.A., Verspagen, J.M.H., Sommeijer, B., 2004. Changes in turbulent mixing shift competition for light between phytoplankton species. Ecology 85, 2960-2970.

Humphries, S.E., Lyne, V.D., 1988. Cyanophyte Blooms: The Role of Cell Buoyancy. Limnology and Oceanography 33, 79-91.

Imberger, J., Patterson, J.C., 1981. A dynamic reservoir simulation model- DYRESM., in: Fischer, H.B. (Ed.), Transport Models for Inland and Coastal Waters Academic Press, New York., pp. 310361.

Imberger, J., Patterson, J. C., Hebbert, B. \& Loh, I. , 1978. Dynamics of reservoir of medium size. Journal of Hydraulics Division ASCE 104, 725-743.

Imberger, J.P., J. C., 1981. A dynamic reservoir simulation model DYRESM:5. In Transport Models for Inland and Coastal Waters (ed. H. Fischer). Academic Press, New York, 310-361. 
Istvanovics, V., 2010. Eutrophication of Lakes and Reservoirs, in: Likens, G.E. (Ed.), Lake Ecosystem Ecology: A Global Perspective. Elsevier, Amsterdam, The Netherlands.

Janssen, A. B., et al., 2015. Exploring, exploiting and evolving diversity of aquatic ecosystem models: a community perspective. Aquatic Ecology, 49(4), 513-548.

Jørgensen, S.E., 2010. A review of recent developments in lake modelling. Ecological Modelling 221, 689-692.

Kara, E.L., Hanson, P., Hamilton, D., Hipsey, M.R., McMahon, K.D., Read, J.S., Winslow, L., Dedrick, J., Rose, K., Carey, C.C., Bertilsson, S., da Motta Marques, D., Beversdorf, L., Miller, T., Wu, C., Hsieh, Y.-F., Gaiser, E., Kratz, T., 2012. Time-scale dependence in numerical simulations: Assessment of physical, chemical, and biological predictions in a stratified lake at temporal scales of hours to months. Environmental Modelling \& Software 35, 104-121.

Khemakhem, Hajer, Jannet Elloumi, Habib Ayadi, Lotfi Aleya, and Mahmoud Moussa. 2013. Modelling the Phytoplankton Dynamics in a Nutrient-Rich Solar Saltern Pond: Predicting the Impact of Restoration and Climate Change. Environmental Science and Pollution Research 20 (12): 9057-65.

Kozhevnikova, I. A., Shveikina, V. I., 2014. Modeling level variations in Lake Kinneret. Water Resources 41, 627-633.

Komárek, J., Anagnostidis, K., 1999. Cyanoprokaryota 1 Teil: Chroococcales. Ettl, H., Gärtner, G., Heynig, G.H. \& Mollenhauer, D. (eds), Süßwasserflora von Mitteleuropa Band 19/1, Spektrum Akademischer Verlag.

Komárek, J., Anagnostidis, K., 2005. Cyanoprokaryota 2 Teil: Oscillatoriales. Büdel, B., Gärtner, G., Krienitz, L. \& Schagerl, M (eds), Süßwasserflora von Mitteleuropa Band 19/2, Spektrum Akademischer Verlag (Elsevier).

Lampert, W., Sommer, U., 2007. Limnoecology, the ecology of lakes and streams. Oxford University Press, New York.

Lurling, M., Eshetu F., Faassen E. J., Kosten S., Huszar V. L. 2013. Comparison of cyanobacterial and green algal growth rates at different temperatures. Freshwater Biology 58: 552-559,

McDonald, C.P., Urban, N.R., 2010. Using a model selection criterion to identify appropriate complexity in aquatic biogeochemical models. Ecological Modelling 221, 428-432.

Mieleitner, J., Reichert, P., 2008. Modelling functional groups of phytoplankton in three lakes of different trophic state. Ecological Modelling 211, 279-291.

Mooij, W., Trolle, D., Jeppesen, E., Arhonditsis, G., Belolipetsky, P., Chitamwebwa, D.R., Degermendzhy, A., DeAngelis, D., Senerpont Domis, L., Downing, A., Elliott, J.A., Fragoso, C., Jr., Gaedke, U., Genova, S., Gulati, R., Hakanson, L., Hamilton, D., Hipsey, M., 't Hoen, J., Hulsmann, S., Los, F.H., Makler-Pick, V., Petzoldt, T., Prokopkin, I., Rinke, K., Schep, S., Tominaga, K., Dam, A., Nes, E., Wells, S., Janse, J., 2010. Challenges and opportunities for integrating lake ecosystem modelling approaches. Aquatic Ecology 44, 633-667.

Naselli-Flores, L., Barone, R., 1997. Importance of water-level fluctuation on population dynamics of cladocerans in a hypertrophic reservoir (Lake Arancio, south-west Sicily, Italy). Hydrobiologia 360, 223-232.

Patten, B.C., Egloff, D.A., Richardson, T.H., 1975. Total ecosystem model for a cove in Lake Texoma., in: Patten, B.C. (Ed.), System Analysis and Simulation in Ecology, Academic Press, New York, pp. 206-423.

Pollingher, U., Hadas, O., Yacobi, Y. Z., Zohary, T. \& Berman, T., 1998. Aphanizomenon ovalisporum (Forti) in Lake Kinneret, Israel. Journal of Plankton Research 20, 1321-1339. 
Rigosi, A., Hanson, P., Hamilton, D.P., Hipsey, M., Rusak, J.A., Bois, J., Sparber, K., Chorus, I., Watkinson, A.J., Qin, B., Kim, B., Brookes, J.D., 2015. Determining the probability of cyanobacterial blooms: the application of Bayesian networks in multiple lake systems. Ecological Applications 25, 186-199.

Rigosi, A., Marcé, R., Escot, C., Rueda, F.J., 2011. A calibration strategy for dynamic succession models including several phytoplankton groups. Environmental Modelling \& Software 26, 697-710.

Rigosi, A., Rueda, F.J., 2012. Propagation of uncertainty in ecological models of reservoirs: From physical to population dynamic predictions. Ecological Modelling 247, 199-209.

Rinke, K., Yeates, P., Rothhaupt, K.-O., 2010. A simulation study of the feedback of phytoplankton on thermal structure via light extinction. Freshwater Biology 55, 1674-1693.

Robson, B.J., Hamilton, D.P., 2004. Three-dimensional modelling of a Microcystis bloom event in the Swan River estuary, Western Australia. Ecological Modelling 174, 203-222.

Romero, J. R., Antenucci, J. P., \& Imberger, J. (2004). One-and three-dimensional biogeochemical simulations of two differing reservoirs. Ecological Modelling, 174(1), 143-160.

Sarnelle, O., 2007. Initial Conditions Mediate the Interaction between Daphnia and Bloom-Forming Cyanobacteria. Limnology and Oceanography 52, 2120-2127.

Slim, K., Fadel, A., Atoui, A., Lemaire, B.J., Vinçon-Leite, B., Tassin, B., 2014. Global warming as a driving factor for cyanobacterial blooms in Lake Karaoun, Lebanon. Desalination and Water Treatment 52, 2094-2101.

Smith, Val H. 2003. Eutrophication of Freshwater and Coastal Marine Ecosystems a Global Problem. Environmental Science and Pollution Research 10 (2): 126-39.

Spigel, R.H., Imberger, J., Rayner, K.N., 1986. Modeling the diurnal mixed layer. Limol. Oceanogr. $31,533-556$.

Stull, R.B., 1988. An introduction to boundary layer meteorology. Kluwer Academic Publishers, Dordrecht.

Takkouk, S., Casamitjana, X., 2015. Application of the DYRESM - CAEDYM Model to the Sau Reservoir Situated in Catalonia. Desalination and Water Treatment 57 (27): 12453-12466.

Tanentzap, A.J., Hamilton, D., Yan, N.D., 2007. Calibrating the Dynamic Reservoir Simulation Model (DYRESM) and filling required data gaps for one-dimensional thermal profile predictions in a boreal lake. limnol. oceanogr.: Methods 5, 484-494.

Temsah, M., Tarhini, K., Fadel, A., Slim, K., 2016. Effect of Irrigation with Lake Water Containing Cylindrospermopsin Toxin on Seed Germination and Seedlings Growth of Cucumis Sativus and Lycopersicon Esculatum. International Journal of Science: Basic and Applied Research 27 (3), 108122.

Tennessee Valley Authority, 1972. Heat and mass transfer between a water surface and the atmosphere. Water Resources Research Laboratory Report 14, Report No. 0-6803.

Tian, Chang, Haiyan Pei, Wenrong Hu, Daping Hao, Martina A Doblin, Ying Ren, Jielin Wei, and Yawei Feng. 2015. "Variation of Phytoplankton Functional Groups Modulated by Hydraulic Controls in Hongze Lake, China." Environmental Science and Pollution Research 22 (22): 18163-75.

Trolle, D., Hamilton, D., Hipsey, M., Bolding, K., Bruggeman, J., Mooij, W., Janse, J., Nielsen, A., Jeppesen, E., Elliott, J.A., Makler-Pick, V., Petzoldt, T., Rinke, K., Flindt, M., Arhonditsis, G., Gal, G., Bjerring, R., Tominaga, K., Hoen, J.t., Downing, A., Marques, D., Fragoso, C., Jr., Sondergaard, M., Hanson, P., 2012. A community-based framework for aquatic ecosystem models. Hydrobiologia $683,25-34$

Trolle, D., Jørgensen, T.B., Jeppesen, E., 2008. Predicting the effects of reduced external nitrogen loading on the nitrogen dynamics and ecological state of deep Lake Ravn, Denmark, using the DYRESM-CAEDYM model. Limnologica - Ecology and Management of Inland Waters 38, 220-232. 
USAID 2012. Litani River Basin Management Support Program. Feasibility study for constructed wetlands in the Litani River Basin. Washington, DC.

Valdespino-Castillo, P., Merino-Ibarra, M., Jiménez-Contreras, J., Castillo-Sandoval, F., RamirezZierold, J.A., 2014. Community metabolism in a deep (stratified) tropical reservoir during a period of high water-level fluctuations. Environmental Monitoring and Assessment 186, 6505-6520.

Vieira, Judite, André Fonseca, Vítor J P Vilar, Rui A R Boaventura, and Cidália M S Botelho. 2013. Water Quality Modelling of Lis River, Portugal. Environmental Science and Pollution Research 20 (1): 508-24.

Wang, W., Liu, Y., Yang, Z., 2010. Combined effects of nitrogen content in media and Ochromonas sp grazing on colony formation of cultured Microcystis aeruginosa. Journal of Limnology 69, 193198.

Wantzen, K., Rothhaupt, K.-O., Mortl, M., Cantonati, M., G.-Toth, L., Fischer, P., 2008. Ecological effects of water-level fluctuations in lakes: an urgent issue. Hydrobiologia 613, 1-4.

Watras, C.J., Baker, A.L., 1988. Detection of planktonic cyanobacteria by tandem in vivo fluorometry. Hydrobiologia 169, 77-84.

Weinberger, S., Vetter, M., 2012. Using the hydrodynamic model DYRESM based on results of a regional climate model to estimate water temperature changes at Lake Ammersee. Ecological Modelling 244, 38-48.

Yeates, P.S., Imberger, J., 2003. Pseudo two-dimensional simulations of internal and boundary fluxes in stratified lakes and reservoirs. Intl. J.River Bassin Mangement, 297-319.

Zhang, X., Warming, T.P., Hu, H.-Y., Christoffersen, K.S., 2009. Life history responses of Daphnia magna feeding on toxic Microcystis aeruginosa alone and mixed with a mixotrophic Poterioochromonas species. Water Research 43, 5053-5062.

Zhou, Jian, Boqiang Qin, Céline Casenave, Xiaoxia Han, Guijun Yang, Tingfeng Wu, Pan Wu, and Jianrong Ma. 2015. Effects of Wind Wave Turbulence on the Phytoplankton Community Composition in Large, Shallow Lake Taihu. Environmental Science and Pollution Research 22 (16): 12737-46.

Zhu, Xuexia, Qianqian Wang, Lu Zhang, Jiaxiuyu Liu, Chen Zhu, and Zhou Yang. 2015. Offspring Performance of Daphnia Magna after Short-Term Maternal Exposure to Mixtures of Microcystin and Ammonia. Environmental Science and Pollution Research 22 (4): 2800-2807. 